\title{
Prof dr A D Pont: \\ 'n Waardering van sy lewe en werk
}

\author{
D J C van Wyk \\ Universiteit van Pretoria
}

\begin{abstract}
Prof dr A D Pont: An appreciation of his life and work

In this article a review of the life and work of Prof A D Pont, minişter of the Nederduitsch Hervormde Kerk and a church historian at the University of Pretoria, Fa. culty of Theology ( $\operatorname{Sec} A)$ is presented. He accepted superannuation at the end of January 1992. The life and work of Professor Pont was closely linked to farreaching happenings, struggle and cataclysmic events in church, theology and politics during his 35 years of office. Therefore a review of his life and work is not merely of personal interest, but of very wide theological and historical interest as well.
\end{abstract}

\section{PERSPEKTIEF}

Die tydperk waarin prof A D Pont die grootste deel van sy teologiese en kerklike arbeid verrig het, was in die Nederduitsch Hervormde Kerk nie altyd baie rustig nie. Kort nadat hy as hoogleraar in teologie aan die Universiteit van Pretoria benoem is, het ' $n$ klein, maar baie aktiewe groep predikante onder leiding van wyle prof $A S$ Geyser, hulle al heftiger teen Artikel III van die Kerkwet van die Nederduitsch Hervormde Kerk begin verset. Dit sou vroeg in die sestigerjare tot ernstige botsings in die Hervormde Kerk, in publikasies en veral tydens Algemene Kerkvergaderings lei. 'n Paar van dié predikante, onder wie proff Geyser, A van Selms en dr C J Labuschagne, tans hoogleraar in Ou-Testamentiese Wetenskap aan die Rijksuniversiteit 
van Groningen, Nederland, het tydens dié stryd die Nederduitsch Hervormde Kerk in 1968 vir goed verlaat.

Naas die stryd rondom Artikel IIl het die Cottesloevergadering van die Wêreldraad van Kerke die Suid-Afrikaanse kerklike wêreld in 1960 ernstig geskud. In 1961 lê drie teologiese studente 'n klag van dwaalleer teen professor Geyser. Dit word 'n moeilike, uitgerekte verhoor en die bevindinge lei uiteindelik tot 'n siviele eis deur Geyser teen die Hervormde Kerk. In 1967 volg 'n lastereis deur dr C F Beyers Naudé en prof Geyser teen prof Pont na aanleiding van beweerde laster in artikels wat hy in Die Hervormer geskryf het.

Sedert die einde van die sestigerjare het 'n ernstige breuk in die Afrikaner se kulturele en politieke lewe sigbaar geword. In dié ontbrandende stryd maak A D Pont ' $n$ ondubbelsinnige keuse waarby hy tot op die huidige oomblik kompromisloos sou bly staan. Dié keuse en sy aktiewe deelname en optrede in die verdere verloop van sake lei in die sewentigerjare tot toenemende ontevredenheid en helaas vereensaming rondom sy persoon.

Maar vanweë prof Pont se intense belangstelling en aanvoeling vir die historiese en sy briljantheid as akademikus en kerkhistorikus is dit terselfdertyd só dat daar baie min uit al hierdie stormagtige jare en gebeure is wat by hom in vergetelheid geraak het; en ook nie net uit diê tyd nie, maar ook ver terug tot in sy kinderjare en veral sy teologiese studiejare. Met ongelooflike presiesheid het hy neergeskryf, bewaar, waargeneem en geïnterpreteer: die konflikte en die spanninge binne die Hervormde Kerk, die verdeeldhede en die stryd tussen mense uit wie die kerk nou maar eenmaal bestaan, die koddighede en die humor rondom leiersfigure, ook die warmte, hartstog en gebondenheid in die kerk, maar helaas ook die liefdeloosheid en vereensaming wat soms deel is van die lewe in die kerk, asook die eerlike besef van eie skuld en foute wat gemaak is.

En nou moet oor dié man se lewe en werk geskryf word. Dit sou maklik gewees het om 'n gladgestrykte oorsig te bied waaruit al die skerp kante, ook die pynlike, weggesny is. Maar dit sou niksseggend wees.

Daar is ' $n$ ander weg gekies: om openhartig oor almal en alles wat op die lang. boeiende weg saam met Pont gekom het, te skryf deur homself telkens aan die woord te stel. Dit is nie net boeiend en interessant nie. Dit is ook van uiterste belang vir die kerk se kerkgeskiedskrywing. Maar daar sal ook verwysings kom na baie mense wat reeds gesterf het, soms persoonlike, selfs onvleiende opmerkings. Lesers sal hopelik wat hier verder volg, teen die agtergrond en perspektief wat hierbo geskets is, lees. 


\section{FAMILIE-AGTERGROND}

Adriaan Drost Pont is op 21 September 1927 in Kroonstad gebore. Sy vader, Johannes Wilhelm Pont (8 Oktober 1898 - 22 Desember 1977) was op dié stadium 'n onderwyser aan die plaaslike hoërskool daar. Sy moeder was Jeanne Louise Agathe Pont (8 April 1899 - 5 Desember 1977), gebore Drost. Sy ouers was Nederlandse immigrante. Sy vader het in 1921 na Suid-Afrika gekom op aandrang van dié se vader, prof Joh W Pont (31 Maart 1863 - 22 Desember 1939). Laasgenoemde was 'n Lutherse teologiese professor en vanaf 1894 tot 1939 sekretaris van Het Studiefonds voor ZA Studenten. Hy was ook vanaf 1911 tot 1936 voorsitter van die Nederlandsch-Zuid-Afrikaansche Vereeniging en as sodanig 'n goeie vriend van SuidAfrika en veral die Afrikaners. Daarom het hy albei sy seuns aangesponr om na Suid-Afrika te emigreer.

Na sy aanvanklike studie in Nederland kom A D Pont se vader, J W Pont (jr) na Suid-Afrika en behaal aan die destydse Grey Kollege in Bloemfontein 'n MSc en O2-diploma, waarna hy gnderwyser word. Teen 1928 sluit hy by die Departement van Landbou aan en werk agtereenvolgens in Pretoria, Fauresmith, Grahamstad en weer in Pretoria. In 1936 behaal hy ook die PhD-graad in plantfisiologie aan die Rijksuniversiteit van Utrecht.

Prof Pont se moeder was 'n predikantsdogter. Haar vader, ds Adrianus Drost was sy lewe lank predikant van die Nederlandse Hervormde Kerk, die laaste jare te Arnhem. Tydens die laast deel van die oorlog, met die mislukte aanval van die Engels-Kanadese magte om die brûe by Arnhem en Nijmegen oor die Ryn te verower, moes hulle vir die oorlogsgeweld uit Arnhem vlug. Sy grootmoeder sterf as gevolg van dié ontberings, terwyl sy grootvader Drost, na wie hy vernoem is, in 1947 in Apeldoorn oorlede is. As tweede seun uit die huwelik van sy ouers is prof Pont dus na sy grootvader aan moederskant vernoem.

Sy vader, J W Pont (jr) tree in 1950 uit die diens van die Departement van Landbou. As spesialis in plantvoeding en saadkwekery aanvaar hy diens in die privaatsektor. Op hulle oudag leef sy ouers in Johannesburg. Vanweë die agteruitgang van sy moeder se gesondheid vind hulle in Ons Tuis, Observatory, 'n laaste toevlug. Hulle is in Desember 1977 enkele dae na mekaar oorlede, sy in die Garden City Kliniek in Johannesburg en sy vader by hom aan huis in Pretoria. Hulle laasie nusplek is in die graf van hulle jonger seun wat in 1949 tragies in 'n ongeluk oorlede is.

\section{SKOOL IEN UNIVERSITETTSOPLEIDING}

Prof Pont is in 1927 in Kroonstad deur sy grootvader, prof Joh W Pont gedoop. Laasgenoemde was, soos reeds gemeld, 'n teologiese hoogleraar in die Lutherse 
Kerk. Ds W J S Plomp was destyds die leraar van die Nederduitse Gereformeerde Kerk in Kroonstad. Hy was as gebore Hollander 'n huisvriend van Pont se ouers en het dit moontlik gemaak dat prof Pont (sr) wat toe op besoek aan Suid-Afrika was, sy kleinseun kon doop. Gedurende die jare waarin die Pontgesin in die Vrystaat gewoon het, het hulle na die Nederduitse Gereformeerde Kerk gegaan.

Sy laerskoolopleiding ontvang Pont in Fauresmith, Grahamstad en aan die Laerskool Pretoria-Oos vanaf 1936. Hy matrikuleer aan die Afrikaanse Hoër Seunsskool in Pretoria in 1943.

Hy behaal in 1946 'n BA-graad aan die Universiteit van Pretoria met hoofvakke Grieks en Hebreeus en in 1949 die BD-graad. In sy studentejare blink hy uit as studenteleier. Gedurende 1948-1949 is hy lid van die Binnemuurse Studenteraad en ook die eerste sekretaris van die Sentrale Studenteraad. In die termyn 1950-1951 is hy voorsitter van die Studenteraad. Einde 1951 ontvang hy die Abe Bailey reisbeurs na Engeland saam met F J Raubenheimer, voorsitter van die Buitemuurse Studenteraad. Gedurende 1947-1949 is hy lid van die Dagstudente Huiskomitee en in 1949 voorsitter. In 1949 is hy assessor van die bestuur van Van der Hoff Teologiese Vereniging.

Oor sy waarnemings en ervarings gedurende sy studiejare laat ons prof Pont verder self aan die woord in ongepubliseerde herinneringe wat hy gedurende 1990 opgestel het en wat van onskatbare waarde is met die oog op ons kerkgeskiedskrywing:

My teologiese studies het in 1947 begin nadat ek die BA met Grieks en Hebreeus voltooi het. Grieks het ek geleer by prof $H$ G Viljoen en prof P V Pistorius, destyds altwee uitnemende dosente. Hebreeus het ek geleer by ds (later prof) E S Mulder, dr A van Selms, toe net terug van sy oorlogservarings in Nederlands Oos-Indië, prof B Gemser en dr P F D Weiss. Latyn het ek geneem by dr Hilgard Muller (later minister van Buitelandse Sake) en prof H L Gonin, Wysbegeerte by prof $\mathrm{C}$ H Rautenbach en prof $\mathrm{T} J$ Hugo.

My tydgenote in die BD I klas was C L van den Berg, J A P van Tonder, J H Naudé en P S van Staden, terwyl H M J Kramer eers in ons finale jaar vanuit Nederland by ons aangesluit het.

Die dosente op dié stadium was prof S P Engelbrecht wat dekaan en hoof was van die Departement Geskiedenis van die Christendom; prof H P Wolmarans wat Godsdienswetenskap, maar eintlik godsdiensfilosofie en godsdienssielkunde hanteer het; prof B Gemser wat hoof van die Departement Ou-Testamentiese Wetenskap was en prof 
A S Geyser wat Nuwe-Testamentiese Wetenskap en Christelike Etiek hanteer het.

\section{S P Engelbrecht}

$S$ P Engelbrecht het met ' $n$ aansteeklike entoesiasme oor die Kerkgeskiedenis lesings gegee, dikwels deurspek met lopende kommentaar oor die sake van die dag. Hy het, soos die gebruik destyds was, diktaatlesings gegee, maar betreklik min gedikteer. As ek my reg herinner, het ek in die finale jaar so iets soos sewe of agt foliobladsye aantekeninge gehad. Sy handboeke was vir die Algemene Kerkgeskiedenis, $\mathbf{H}$ Berkhof se Geschiedenis der Kerk wat toe baie nuut was en 'n uitstekende handboek. Vir die Nederlandse Kerkgeskiedenis het ons J Reitsma en J Lindeboom se Geschiedenis van de Hervorming en de Henvormde Kerk der Nederlanden gebruik. Vir Dogmengeskiedenis het ons nie ' $n$ spesifieke handboek gekry nie.

Engelbrecht se lesings was daarop gemik om ons 'n mate van insig in die gang van die geskiedenis te gee. Hy was redelik oorsigtelik in sy lesings en was baie lief om anekdotes en interessanthede van die verskillende personalia uit die kerkgeskiedenis te vertel. Op dié manier het hy ons heelwat detail-besonderhede in sy lesings gegee en ons aandag daarop gevestig dat dit dikwels klein dingetjies was wat groot gevolge gehad het.

Gedurende my tyd het hy geen lesings oor die Suid-Afrikaanse Kerkgeskiedenis gegee nie, maar slegs sy Geskiedenis van die Nederduitsch Hervormde Kerk van Afrika voorgeskryf. Dié moes ons egter baie goed ken vir die eksamen. Dit het meegebring dat ons dikwels in die periodes wat geoormerk was vir die Algemene of Nederlandse Kerkgeskiedenis, vrae oor die Suid-Afrikaanse Kerkgeskiedenis gestel het en só Engelbrecht aan die praat gekry het oor die geskiedenis wat hy met 'n merkwaardige kennis van besonderhede tot in die fynste puntjies geken het.

Engelbrecht se manier van onderrig gee en sy intense betrokkenheid by sy vakgebied het aansteeklik gewerk en daar was seker min studente wat nie met waardering vir die geskiedenis van die kerk, uit sy lesings gestap het nie. 'n Merkwaardige faset van Engelbrecht was dat hy in die beste sin van die woord net én belangstelling en eén onderwerp gehad het waaroor hy kon praat en dit was die kerkgeskiedenis. Hy het elke gesprek altyd weer op een of ander manier by sy 
vakgebied uitgebring en dan lekker gesels. Hy het nie alleen oor 'n fenomenale geheue beskik nie, maar het ook die genealogie van die meeste Transvaalse families op die punte van sy vingers geken.

Engelbrecht het in ons tyd ook Dogmatiek doseer. Oorspronklik is prof $\mathrm{J} \mathrm{H} \mathrm{J} \mathrm{A} \mathrm{Greyvenstein} \mathrm{aangestel} \mathrm{om} \mathrm{Nuwe-Testamentiese}$ Wetenskap, Dogmatiek en Christelike Etiek te hanteer. Hy het in 1939 die vak Christelike Etiek aan C H Rautenbach oorgedra wat dit op bekwame wyse gedoseer het.

Met Geyser se omstrede aanstelling tot opvolger van Greyvenstein het hy die opdrag gekry om al die vakke wat Greyvenstein oorspronklik hanteer het, vir sy rekening te neem.

In 1943 het Greyvenstein die aftree-ouderdom van 65 jaar bereik. Aangesien daar in die Kerk niemand was wat in die Nuwe- Testamentiese Wetenskap gepromoveer was nie en vanweë die oorlog dit ook nie moontlik was om 'n moontlike opvolger uit Nederland te bekom nie, is Greyvenstein se aanstelling gekontinueer.

Dit was waarskynlik Engelbrecht se invloed wat gemaak het dat daar geen promovendi uit die Fakulteit na vore gekom het nie. Engelbrecht was daarvan oortuig dat alleen 'n Afrikaner wat in Nederland gepromoveer het of 'n Nederlander akademies sterk genoeg kon staan om in aanmerking te kom vir 'n professoraat. Toe ek wou verder studeer, wou Engelbrecht nie vir 'n enkele oomblik daarvan weet dat ek onder hom sou studeer nie. Vanweë die oorlog was daar toe ook nie 'n kans om 'n belowende student na Nederland te stuur nie en die Universiteit van Pretoria was, volgens Engelbrecht, nie goed genoeg nie!

In 1945 is Geyser as opvolger van Greyvenstein benoem. Omdat hy nog nie gepromoveer was nie, het hy in 1946-1947 as lektor opgetree. In 1947 het hy aan die Universiteit van Pretoria gepromoveer met 'n proefskrif: Die geslagsregister van Jesus Christus volgens Matheus 1:1-17 en Lukas 3:23-38. Oor dié proefskrif was daar heelwat bedenkings daar prof H P Wolmarans en 'n eksterne eksaminator, prof E P Groenewald, 'n onvoldoende punt daaraan toegeken het.

A S Geyser was ' $n$ beskermling van prof $S$ P Engelbrecht en die keuse van die destydse Sappe in die kerk. Ds S P J J van Rensburg, wat Greyvenstein se keuse as opvolger was en die steun van die Afrikaners soos H P Wolmarans en A J G Oosthuizen gehad het, is deur die Fakulteit vertraag deurdat van hom verwag is om 'n doktorale 
eksamen af te lê oor al die teologiese vakke. Vanweë Van Rensburg se deeglikheid het hy die studieopdrag baie sorgvuldig uitgevoer en, as gevolg daarvan, nie betyds sy kursus voltooi nie.

Juis daarom het Geyser se aanstelling selfs in die Algemene Kerkvergadering aanleiding tot twiste gegee.

Sommer met die intrapslag het Geyser die fout begaan om Rautenbach as lektor te vervreem en om self Christelike Etiek oor te neem. Dit waarskynlik omdat Rautenbach ook sy aanstelling teengestaan het. Dit het weer veroorsaak dat Rautenbach hewig daaroor geïrriteer was en omdat die destydse Kuratorium en Kommissie van die Algemene Kerkvergadering die saak so aanvaar het, het hy nie baie waardering vir die Teologiese Fakulteit gehad nie. Gedurende die jare wat Rautenbach rektor was, het hy waar hy kon, die Fakulteit geraps en die Fąkulteit steeds met arendsoë dopgehou en die kleinste afwyking dadelik en ongenadiglik tereggewys. Selfs toe ek al dosent was, het Rautenbach 'n keer vir E S Mulder, wat toe dekaan was, ongelooflik baie moeite besorg omdat een of ander voorlegging van die Fakulteit aan die Senaat nie presies in orde was nie.

Engelbrecht se dogmatiek-lesings het ons oonuig dat dit wat hy doseer, nié dogmatiek kon wees nie. Daar was op daardie stadium toe al manne soos Ben Engelbrecht en Ben Venter wat ten opsigte van die Dogmatiek hulle eie gang gegaan het en alles en nog wat gelees het. Daarby het hulle hulp gaan soek by prof $\mathrm{H}$ P Wolmarans wat hulle aandag gevestig het op die werk van die manne van die Dialektiese Teologie. Jare later het Ben Venter my 'n hele versameling uitgawes van Karl Barth en Thurneysen se tydskrif Theologische Existenz Heute present gegee wat hy al as student deurgewerk het.

Daardie invloed asook die feit dat Engelbrecht vanaf my tweede jaar G C van Niftrik se Kleine Dogmatiek voorgeskryf het, het my aandag op die Dialektiese Teologie gevestig. So het dit gebeur dat ek, met 'n absolute minimum kennis van Duits en slegs met 'n Duitse Woordeboek gewapen, begin het om Karl Barth se Kirchliche Dogmatik deur te werk. Dit enersyds omdat ek wou weet en andersyds om te kan bybly by die gesprekke wat daar tussen die studente gevoer is.

Die groep studente wat so met die Dialektiese Teologie gespook het, was nie 'n georganiseerde groep nie, maar slegs 'n klompie vriende wat 'n gesamentlike belangstelling gehad het. As ek hier name kan noem, dan sou ek sé dat dit manne soos J P B Venter, C L van den 
Berg, C J Mans, J P Oberholzer, C J S van Niekerk, J I de Wet, C G Botha en derglike was wat die voortou geneem het. Die vlak van ons bedrewenheid was seker nie baie hoog nie, maar wat my betref, het die Dialektiese Teologie vir my 'n baan in die teologie gebreek. Hier sou ek tog iets oor Ben Venter wil sé. Hy het met sy hoë lees- en retensievermoë nie net teologie gelees nie, maar ook die 19e- en 20eeeuse filosowe soos Heidegger en deur hom het ek heelwat van die filosofie geleer. Die inligting is gewoonlik uitgeruil in lang gesprekke wanneer ons koffie in die Klubsaal gedrink het, of tussen lesings aan die gesels geraak het.

Dit was interessant dat Engelbrecht self nie veel waardering vir Barth gehad het nie en as ons Barth se menings in die lesingsaal na vore gebring het, het hy gewoonlik negatief gereageer. Dan het hy sy toevlug geneem tot die reformatoriese belydenisskrifte en op dié manier ons op sy beurt tog weer heelwat geleer van die waarde van die reformatoriese teologie. So het dit gebeur dat Engelbrecht se dogmatiek-lesings ons op nuwe, interessante paaie gevoer het, sonder dat hy dit so wou gehad het.

Miskien kan ek net bysê dat ons ook heelwat stimulasie vir ons denke by Van Selms gekry het wat, in die een jaar wat hy vir ons eksegese gegee het toe Gemser met studieverlof was, ons iets geleer het van die teologiese eksegese soos dit deur die dialektici na vore gebring is. Dit was baie interessanter as Gemser se ietwat droe literêrhistoriese eksegese met sy ellelange verwysings na die verwante materiaal in die Ou Nabye Oosterse literatuur.

\section{H P Wolmarans}

Ons belangstelling in die Dialektiese Teologie het, wat my betref, my in staat gestel om H P Wolmarans se lesings in die Godsdiensfilosofie te volg. Wolmarans het 'n eiesoortige doseermetode gehad. Sy eie, stokou opsomming van Emil Brunner se Der Mittler moes deur die studente oorgeskryf word en het dan as basiese werkopgawe gedien. In die lesings het Wolmarans dan kommentaar gelewer op Brunner se argumente. Van besondere waarde vir my was sy lang en baie deeglike uiteensettings oor die voorveronderstellings waarmee enige teoloog en wetenskaplike werk. Juis daarmee het Wolmarans my oë oopgemaak vir die feit dat die teologie 'n veelduidige wetenskap is en dat dit uit verskillende invalshoeke benader word en alleen verstaan kan 
word as die teoloog se voorveronderstellings ook sorgvuldig bereken word.

Wolmarans se lesings oor Der Mittler, waar hy ook ons aandag gevestig het op Rudolf Otto se beroemde werkie, Das Heilige, het my oë oopgemaak vir die oneindige afstand tussen God en mens. Die feit dat God vir die mens die groot Onkenbare is en alleen geken kan word vir so ver $\mathrm{Hy}$, in sy ontferming, Hom aan die mens openbaar, het my denke in hierdie verband permanent bepaal. Dit kon nie juis anders nie, want as daar én saak was waaroor Wolmarans voortdurend gepraat het, dan was dit juis die openbaring en wat dit beteken.

By Wolmarans moes mens baie goed luister om reg te verstaan, want hy sou ' $n$ sin of 'n paragraaf van die opsommings lees en dan, terwyl hy peinsend oor sy baard stryk, vra: En wat bedoel hy nou as hy só sê? Dit was dan die aanloop tot 'n diskussie of 'n betoog waar Wolmarans daarin geslaag het om ons aandag vas te hou en waar hy ons geleer het om teologies te dink. Die merkwaardige was dat Wolmarans juis s6, seker dié dosent was wat die deurslaggewende teologiese invloed op ons studente gehad het. Vanselfsprekend het ons by die verskillende dosente baie geleer, maar Wolmarans het, met die klem. tone wat hy gelê het, ons oë oopgemaak vir die objektiewe reformatoriese teologie. Ek wil dit waag om te sê dat Wolmarans, met sy merkwaardige manier van lesings gee en sy manier om die mees ingewikkelde saak in gewone Afrikaans aan die studente oor te dra, die man was wat die nuwe belangstelling in die reformatoriese teologie, wat die kenmerk van die 'tweede fakulteit' (histories gesproke) was, gestimuleer het. Immers, Ben Engelbrecht, Frans van Zyl, Koos de Wet en ekself het elkeen op sy manier tog binne die denke van die reformatoriese teologie beweeg. Daarin was ons almal studente van Wolmarans.

\section{B Gemser}

By Gemser was ons lesings gewoonlik lang, baie sorgvuldige en presiese diktate oor die betekenis van woorde en begrippe. As daar een saak is wat Gemser by ons ingedril het, dan was dit eksaktheid. Gemser bet nog eksegese gedoen volgens die opvattings van die literér-historiese skool en sy lesings het gewoonlik gewemel van verwysings na die Assiriese, Babiloniese en Egiptiese dink- en leefwèreld. Vir die prediking was dié soort eksegese grotendeels waardeloos, maar by 
Gemser het mens nie in die klas gepraat nie. Ons het sy werk met groot toewyding voorberei en ons is geleer om tekskritiese probleme te hanteer, om die grammatika op die punte van ons vingers te ken en om vlot te vertaal en te begryp wat ons vertaal. Die materiaal wat ons in die lesings gekry het, moes ons memoriseer. Die inleidingskwessies, onder andere die bronne splitsingsteorieë ten opsigte van die Pentateuch, die aardrykskunde en die teologie van die Ou Testament moes ons saam met 24 hoofstukke selfstudie, alles self doen en dit ken!

Gemser met sy formele, korrekte en beleefde manier van klasgee het ons almal uitermate beindruk en sy omgang met ons het inderdaad 'n opvoedende en beskawende invloed op ons uitgeoefen. By Gemser het niemand dit ooit gewaag om klas af te gee, onvoorbereid in die lesing te kom, of om op een of ander manier die indruk van slordigheid of onvoorbereidheid te gee nie. Dan kon dié beleefde en waardige man met 'n paar snydende opmerkings 'n slagoffer reduseer tot 'n baie verleë en bekommerde student.

\section{A S Geyser}

Geyser se lesings het my as student nooit beïndruk nie. Hy het ' $n$ ietwat arrogante styl gehad en 'n beterweterige houding wat ek nooit kon verwerk nie. Teologies het ek bitter min by hom geleer, want hy het ook met 'n soort literêr-historiese eksegese vorendag gekom, maar hy het nie die breë verwysingsraamwerk van Gemser gehad nie.

By Geyser het ons ook Praktiese Teologie gekry, dit wil sề: homiletiek en praktiese preekoefeninge. Die preekoefeninge, gewoonlik in die week op 'n Donderdagaand gehou, was maar baie vermoeiend omdat Geyser veral op die vorm baie nadruk gele het, maar inhoudelik ons nie veel kon leer nie. Vandaar dat ons meer belanggestel het in die Dialektici se teologiese eksegese en wat ons preekwerk betref, ons probeer modelleer het op ds Simon Vermooten, toe predikant van Pretoria. Hy was, wat my betref, een van die groot kanselredenaars wat die Nederduitsch Hervormde Kerk gehad het.

Ek het later in Utrecht spesiaal Praktiese Teologie as byvak by prof S F H J Berkelbach van den Sprenkel gaan volg om te probeer vasstel wát die inhoud van die vak was.

Geyser was die enigste dosent met wie ons as studente ooit struwelinge gehad het. Meer as een maal, veral tydens sy eksegese le- 
sings, het ons hom weerspreek, sy eksegese in twyfel getrek en met kontra-argumente na vore gekom.

Ten siotte. As studente was ons destyds almal maar bitter arm. Immers, in die jare net na die oorlog was geld skaars en die meeste van ons moes met 'n absolute minimum klaarkom. Van my ouers het ek 2/6 per maand sakgeld gekry, terwyl my Oom Daan, toe Dekaan van die Regsfakulteit, my ' $n$ maandelikse toelaag van een pond gegee het. Daarmee was ek betreklik ryk.

Vir ons onderhoud het ons as studente maar in die somervakansies gewerk waar ons 'n werkie kon kry en daarmee het ons vir die jaar klere gekoop en so 'n bietjie geld gebère vir sakgeld. Ek was gelukkig in dié sin dat ek by my ouers kon bly waar ons in Parkstraat 978, Hatfield gewoon het. Dit het beteken dat ek vir die eerste drie jaar van my studie universiteit toe gery het met die fiets, maar daarna, vanweë my verhoogde status as teologiese student, gestap het. Dit was ook nie so vreemd nie as mens bedink dat 'n man soos prof S P Engelbrecht sy lewe lank van Lisdoganlaan af universiteit toe gestap het. Hy het eers in my vierde of vyfde jaar sy huis afbetaal gekry (my ouers is nog genooi na die feesmaal wat hy aangerig het om die gebeure te vier) en daarna het hy eers 'n kar gekoop. Dit was so 'n swart vier-silinder Citroen en vir die jare wat hy met die motorkar rondgery het, was hy vir homself en alle ander padgebruikers 'n lewensgevaar. ' $n$ Mens het net in uiterste noodsituasies saam met Oom Fanie in 'n kar geklim as hy bestuur het.

(Pont 1990:2-7)

\section{PROP(DNLNT EN NAGRAADSE STUDIE}

Aan die einde van 1949 lê Pont die proponentseksamen af. Hy was egter nie beroepbaar nie omdat hy te jonk was. Destyds moes 'n proponent 23 jaar wees om beroep te word. Hy was toe knap 22 jaar.

Omdat sy junger broer, Karel Frits op 21 Mei 1949 verongeluk het, wou hy ter wille van sy ouers nie uit die huis nie. Daarom besluit hy om met groot erns die studie in 'n MA in Grieks verder te voer.

Juis in daardie tyd word hy gevra om in Silverton te werk. Die gemeente was toe nog 'n konsulentsgemeente wat te klein was om te beroep. Dit was veral die ouderlinge J P Snyman, Koot en Piet van der Merwe saam met Hennie Swanepoel wat die skriba was, wat groot invloed op sy vorming as predikant gehad het. In dié tyd 
leer hy ook ds J D Storm ken wat die konsulent was en het van hom geweldig baie geleer. Terselfdertyd het ds (later prof) E S Mulder, toe predikant van Pretoria, hom ook oor Pont ontferm. Die raad en vorming van dié manne roep hy steeds dankbaar in herinnering.

Ná afloop van die Abe Bailey-toer deur Engeland studeer Pont vanaf Januarie 1952 tot Junie 1955 in Nederland. Gedurende 1952 voltooi hy sy MA-studie in Utrecht met lof. Die verhandeling was getitel: 'Die Britse Museum Papyri nos 19131919 van ' $n$ inleiding, vertaling en enkele aantekeninge voorsien.' Prof P V Pistorius van die Universiteit Pretoria het deur korrespondensie as studieleier opgetree.

Hy lê in 1954 'n doktorale eksamen af met Kerkgeskiedenis as hoofvak onder prof $\mathrm{M}$ van Rhijn as promotor. Sy byvakke was Ou-Testamentiese Wetenskap onder A H Edelkoort en Praktiese Teologie onder S F H J Berkelbach van der Sprenkel. Hy promoveer aan die Rijksuniversiteit te Utrecht op 30 Junie 1955 tot doctor theologiae met as proefskrif, Nicolaas Jacobus van Warmelo, 1835-1892.

In sy herinneringe vertel Pont:

Gelukkig was daar 'n spannetjie interessante Afrikaners in Utrecht en in Nederland met wie ek goeie vriende geword het. In Utrecht was ek mede-oprigter en die eerste voorsitter van Die Genootskap van Afrikaners in Utrecht wat ons in 1952 opgerig het. In daardie jaar het ons ook die Van Riebeeckfees in Culemborg help beplan en vier en nogal heelwat versit om dr Pellissier en sy groep volkspelers in Nederland rond te neem.

Saam met A M Hugo en W J B Serfontein skryf en publiseer ons Suid-Afrikaners in Utrecht 1762-1954, Utrecht 1954. In daardie selfde jaar skenk ons as genootskap 'n bronsplaat aan die universiteit om die akademiese verbintenis van die Universiteit met Suid-Afrika te beklemtoon. Dit was veral Serfontein se gedagte en hy het baie moeite gedoen om die projek te finansier. Die plaat is op 10 Oktober 1954 onthul in die hoofgebou op die Domplein. Tydens die haatveldtog teen Suid-Afrika is die bronsplaat glo verwyder. Wat daarvan geword het, is my onbekend.

(Pont 1990:8)

\section{AS PREDIKANT AAN DIE OOS-RAND}

Ná sy terugkeer na Suid-Afrika in Julie 1955 word Pont deur die Nederduitsch Hervormde Gemeente Elsburg beroep. In Elsburg het hy lekker gewerk. Sy bure, so vertel hy, was Hans van Staden in Germiston en in Boksburg was Bart Oberholzer. 
In 1956 het Bart en hy, vol jeugdige ywer, Die Oos-Randse Kategismus geskryf! Dit was 'n uitleg van die Apostolicum, die Dekaloog en die Ons Vadergebed ter aanvulling van die Kort Begrip. Dit was veral hulle gemeentes se katkiseermeesters wat baie waardering daarvoor gehad het, aangesien daar destyds nie so-iets in die Hervormde Kerk bestaan het nie.

\section{HOOGLERAAR VANAF 1957}

Hy werk in Elsburg tot aan die einde van 1956. Vanaf 1 Februarie 1957 is hy op voordrag van die Kuratorium vir Teologiese Opleiding aangestel as professor in en hoof van die Departement Geskiedenis van die Christendom (soos dit destyds nog bekend was). Hy volg prof S P Engelbrecht, wat aan die einde van 1956 afgetree het, op.

Oor die herinnering aan sy werk aan die Fakulteit, laat ons weer vir professor Pont self aan die woord:

Met my aanstelling is ek heeltemal aan die diep kant ingegooi. Ek was knap 29 jaar en nog rou en onervare en van doseerwerk het ek net mooi niks geweet nie. Van die geskiedenis van die Nederduitsch Hervormde Kerk van Afrika het ek heelwat geweet en buitendien was prof S P Engelbrecht se Geskiedenis van die Nederduitsch Henormde Kerk van Afrika (derde druk 1953) nog nuut. Daar het ek dus 'n handboek gehad.

Die res van die vakopdrag het egter vir my probleme geskep, want ek moes ook lesings gee oor die Algemene Kerkgeskiedenis, die Dogmageskiedenis, die Nederlandse Kerkgeskiedenis en Kerkreg. Buitendien was dit nog die tyd van diktaatlesings, sodat ek elke dag met 'n geskrewe teks voor die studente moes staan.

In my eerste jaar as professor het 'n betreklike groot ramp my ook nog getref. In die nag van 12 en 13 September 1957 het 'n weerligstraal die grasdakhuis in Carinastraat, Waterkloofrif, wat ek saam met twee vriende, dr P J Kotze en S F Geyer bewoon het, aan die brand geslaan. In dié brand is my totale en nogal omvangryke boekery totaal vernietig. Dié boekery het nogal waardevolle boeke bevat wat ek in Nederland gekoop en present gekry het asook al die boeke wat ek tydens my studietyd aan UP aangekoop het. Daarby het al my persoonlike besittings wat ek van 1927-1957 bymekaargemaak het, ook afgebrand, onder andere al my graadsertifikate. Die volgende móre moes ek by die buurman, wat hom oor ons ontferm het, 'n broek en 'n 
hemp leen, sodat ek kaalvoet stad toe kon gaan om weer die allernodigste klerasie te koop.

Die eerste tien jaar by die Fakulteit was moeilike en ook onrustige jare. Moeilik omdat ek my voete moes vind. Daarin is ek egter op voortreflike wyse bygestaan en ondersteun deur prof H P Wolmarans, asook prof E S Mulder met wie ek altyd baie goed bevriend was en wat deur dik en dun ' $n$ vriend en vaderfiguur vir my gebly het. Dan moet ek ook Ben Engelbrecht se naam noem wat nooit moeg geword het om met sy enorme geheue my te help en raad te gee en teologiese kwessies vir my te verduidelik en deursigtig te maak nie. Wat ek sonder dié drie manne se ondersteuning en hulp sou gedoen het, weet ek nie.

(Pont 1990:10)

\section{BOTSING MET PROFESSOR A S GEYSER}

Om die botsing tussen wyle prof A S Geyser en die Nederduitsch Hervormde Kerk asook die hewige konflik tussen Geyser en Pont te begryp, is dit nodig om kortliks te let op die uiters gespanne, plofbare atmosfeer wat vanaf 1960 in die Suid-Afrikaanse politieke en kerklike situasie opgelaai het.

Gedurende Maart 1960 kondig dr H F Verwoerd in 'n dramatiese ontwikkeling in Londen aan dat Suid-Afrika die Britse Statebond verlaat. Gedurende dieselfde maand skiet die polisie 69 swartmense tydens onluste in Sharpeville naby Vereeniging dood. Histerie bars wêreldwyd teen Suid-Afrika los. Eerste gevalle van ernstige sabotasie kom voor. Gedurende April word 'n sluipmoordaanval tydens die Randse Paasskou deur David Pratt op dr HF Verwoerd uitgevoer. Verwoerd oorleef twee kopskote op kort afstand afgevuur. In 'n uiters gespanne situasie vind die Cottesloevergadering van die Wêreldraad van Kerke in Johannesburg gedurende Desember plaas. Dit word voorafgegaan deur die verskyning van die boekie, Vertraagde Aksie waarin 'n striemende aanval op die apartheidsbeleid in Suid-Afrika geloods word. Daarin lewer onder andere ook proff A S Geyser en A van Selms bydraes. Nadat die afvaardigings van die Nederduitse Gereformeerde Kerke aanvanklik saam met die bevindinge van die beraad stem, spring hulle kortom toe die afvaardiging van die Nederduitsch Hervormde Kerk hom daarvan distansieer en 'n ernstige botsing met Verwoerd dreig. 'n Wekelange verwarring volg met botsende verklarings onr en weer.

In Maart 1961 vind die drie en vyftigste Algemene Kerkvergadering van die Nederduitsch Hervormde Kerk plaas. Geyser, Van Selms en enkele ander teoloë 
loods 'n heftige aanval op Artikel III van die Kerk se Kerkwet, waarin onder andere lidmaatskap van die Kerk tot blankes beperk word. Later in die jaar lê drie teologiese studente 'n klag van dwaalleer teen prof Geyser. Ná 'n uitgerekte verhoor waarvan die rekords bykans 3000 bladsye beslaan en wat duur van Oktober 1961 tot Mei 1962 word Geyser as predikant van die Kerk deur die Kommissie van die Algemene Kerkvergadering afgesit. Hy bedank self as hoogleraar aan die Universiteit van Pretoria en aanvaar ' $n$ betrekking aan die Witwatersrandse Universiteit.

In Mei 1963 begin 'n saak waartydens Geyser hom op die hooggeregshof beroep. Hy beweer onder andere dat die Kommissie van die Algemene Kerkvergadering geprejudiseer was en mala fide teen hom opgetree het. As hy vroeg in die saak bely dat hy die Athanasianum volledig en saam met die kerk bely en dat sy eksegese van Filippense 2:1-11 nie sy volledige oortuigings oor die Christologie bevat het nie, lei dit tot 'n skikking waarin die Hervormde Kerk as gebaar van welwillendheid verklaar dat Geyser steeds predikant van die Nederduitsch Hervormde Kerk is en onderneem om al die hofkostes te betaal.

In April 1964 volg die vier en vyftigste Algemene Kerkvergadering in Pretoria. Geyser word toegelaat om die vergadering 'n uur lank toe te spreek. Hy loods 'n striemende aanval op die Kommissie van die Algemene Kerkvergadering oor sy hantering van die tugsaak. As die vergadering weier dat hy, nadat ook die Kommissie sy saak gestel het, repliek lewer, verlaat Geyser die vergadering. Hy kondig in 1968 tydens 'n gesprek met die Kommissie van die Algemene Kerkvergadering aan dat hy die Nederduitsch Hervormde Kerk verlaat.

Gedurende al dié gebeure tree professor A D Pont al sterker na vore as teenstander van die denkrigtings en optrede van Geyser. Op albei Algemene Kerkvergaderings vind hewige botsings tussen hulle plaas.

'n Sameswering teen die Suid-Afrikaanse regering wat beplan was om die owerheid teen 1965 tot 'n val te laat kom, word gefnuik deur grootskaalse arrestasies tydens 'n klopjag in 1963 deur die Polisie in Rivonia naby Johannesburg.

In April 1964 word 'n Anti-Kommunistiese Kongres van 2000 deelnemers in Pretoria gehou. Die Kongres is ' $n$ uitvloeisel van 'n voorstel wat Pont tydens 'n rapportryerbyeenkoms maak. Hy speel ook 'n prominente rol tydens die kongres. Op 6 September 1966 volg die iweede sluipmoordaanslag op dr Verwoerd, hierdie keer met noodlottige gevolge.

Oor sy botsing met Geyser skryf Pont:

Geyser het die flater gemaak om die basiese Engelse kerkbegrip aan te hang. Immers, in die Engelse wèreld funksioneer die kerk nié as die geroepe volk van God wat die evangelie van Jesus Christus moet uitdra nie, maar as 'n politieke magsmiddel of hefhoom in die hande 
van die owerheid of politieke magte. Dit is die lot van die ecclesia Anglicana vanaf die dae van Henry VIII wat, ter wille van sy behoefte om 'n seun as troonopvolger te hê en so die Tudor-dinastie te vestig, die pous se seggenskap oor die ecclesia Anglicana afgesweer het en toe die kerk onder sy persoonlike gesag as staatskerk geplaas het. Daarvandaan funksioneer die kerk in die Engelse wêreld as 'n verlenging van die koning of die owerheid se gesag en teologies is dit nie veel meer as 'n instituut wat 'n deugdeleer verkondig wat inpas by die koers van die politiek nie.

Dié verskuiwing in die Engelse teologiese en kerklike wêreld kon nie deur die invloed van die calvinisme gestuit word nie en Henry VIII se opvattings is veral deur Elizabeth I finaal geyk. Daarvandaan het die ecclesia Anglicana eintlik opgehou om teologies relevant te wees.

Hierdie denke oor die posisie en funksie van die kerk is deur die Engels-Amerikaanse kerke in die Wèreldraad van Kerke ingedra en dit is ook verstaanbaar omdat hulle die Wêreldraad van Kerke finansieel dra.

Die botsing met Geyser was, in diepte gesien, ook 'n botsing oor die kerkbegrip, want hy wou die Nederduitsch Hervormde Kerk van Afrika omvorm om op die politieke terrein standpunt teen die regering in te neem en om met ' $n$ oppervlakkige, horisontale moralisme soos 'n Wêreldraad van Kerke-tipe kerk te funksioneer. In hierdie botsing waar dit gegaan het oor die vraag of die Nederduitsch Hervormde Kerk van Afrika sou staan by sy Skriftuurlike en calvinistiese kerkbegrip, het Geyser die stelling probeer regverdig dat die Nederduitsch Hervormde Kerk van Afrika deur die Nasionale Party en die Broederbond gedomineer is en nie selfstandig teologies dink nie. Met ander woorde, hy het vanuit sy kerklik-politieke vertrekpunt geoordeel dat die Kommissie van die Algemene Kerkvergadering en die Fakulteit dieselfde kerkbegrip as hy gehad het, maar slegs ander politieke uitgangspunte gehad het. Dit was natuurlik nie waar nie.

(Pont 1990:11)

\section{DIE LASTEREIS}

Gedurende Junie 1964 vind 'n internasionale konferensie in Mindolo, Zambië plaas. Dié konferensie, gereël deur die Wêreldraad van Kerke, die South African Institute for Race Relations en die All African Churches Council, moes handel oor aksies om 
verandering in sosiale en rasseverhoudinge in Suid-Afrika teweeg te bring en veral die rol van die kerk daarin. Onder die teenwoordiges was ook prof A S Geyser en dr C F Beyers Naudé. Volgens ingeligte bronne destyds het die Ford-stigting die byeenkoms geborg.

Ná die nekslag wat die kommuniste by Rivonia toegedien is, moes gepoog word om die kerk in te span om die so begeerde verandering in Suid-Afrika te bewerkstellig. Die vraag was: hoe? Die Mindoloberaad moes op dié vraag antwoord.

In sy Kroniek in Die Henormer in dié tyd kom Pont op die Mindoloberaad terug, en lê hy die inhoud van die beraad bloot.

Vanaf 15 Februarie tot 21 April 1967 volg 'n lastersaak in die hooggeregshof waarin Geyser en Beyers Naudé skadevergoeding van Pont eis omdat hy hulle sou geïdentifiseer het as kommuniste, kommunistiese meelopers en voorstanders van revolusie en sabotasie in Suid-Afrika.

Die eisers self het verkies om nooit in die getuiebank te verskyn nie. Pont het getuig vanaf 28 Februarie tot 9 Maart en is deur advokaat G A Coetzee aan kruisverhoor onderwerp vanaf 10 tot 31 Maart.

Die saak is deur die eisers gewen. Sterk finansiële steun het uit die buiteland vir hulle gekom. Die saak is wyd beoordeel as 'n toetssaak tussen die liberale kerklike, sosiale en politieke magte wat ernstige knoue by Cottesloe en Rivonia opgedoen het, en die konserwatiewe magte in Afrikanerdom, veral die Afrikaanse kerke.

Oor die lastersaak se aanloop en nadraai skryf Pont:

In die maandelikse Kroniek wat ek op versoek van ds Joh Dreyer in Die Hervormer behartig het, het ek gepoog om die Wèreldraad van Kerke en sy soort teologie aan die kaak te stel. Dit was vir my duide. lik dat die Wêreldraad van Kerke se tipe teologie nie in die Nederduitsch Hervormde Kerk van Afrika 'n staanplek verdien het nie omdat dit wat uitgangspunt en deurwerking betref, lynreg teenoor die reformatoriese teologie gestaan het. My opvattings in hierdie verband het nogal duidelik deurgekom in die proefskrif van Rolf Sauerzapf, Die Säkularisierung der Genfer oekumene wat hy onder my promotorskap aangebied het...Die hofsaak was nogal interessant omdat dit duidelik aangetoon het wár my vriende en kennisse gestaan het. Nadat ek die saak verloor het, het dit nogal stil om my geraak. Dit was duidelik ek het vir baie van my vriende en kennisse 'n verleentheid geword. Maar daar was ook manne wat deur dik en dun by my gestaan het en om 'n paar te noem: Albert Herbst wat seker een van die lojaalste vriende is wat ek ooit in die Kerk raakgeloop het, Jaap Marais wat met sy insig en intuitiewe wete so dikwels vir my 'n inspi- 
rasie was, Willem Marais, en dan manne soos di Andries Nolte, Andries Oosthuizen, Stoffel Botha en Smous Mans; selfs destyds Gert Pelser, Freek van der Merwe, Gert van Staden, Rassie Kotzé, Johan Steenkamp en nog meer.

(Pont 1990:13)

\section{OMSTREDENHEID WEENS POLTTEK}

Professor A D Pont was sy hele loopbaan as predikant, teoloog en hoogleraar deur 'n sterk omstrede figuur. Dit is te wyte aan 'n sterk mate van uitgesprokenheid, skerp teologiese insigte en belesenheid, lewendige belangstelling in politiek, landen wêreldsake, kompromislose liefde vir kerk en volk, 'n aggressiewe skryfstyl, onverskrokkenheid en les bes, 'n goeie mate van moedswilligheid. Sowel sy skryfstyl as sy betrokkenheid in party-politieke sake het meermale aan ampsdraers en lidmate aanstoot gegee en vir hom persoonlike vyandskap op die hals gehaal.

Oor sy politieke betrokkenheid skryf Pont self:

$\mathrm{Na}$ die hofsaak het ek in 1969 die leiding gevolg van dr Albert Hertzog, mnre Jaap en Willem Marais en Louis Stoffberg en meegewerk aan die stigting van die Herstigte Nasionale Party. My deelname aan die stigting van die Herstigte Nasionale Party het gesentreer rondom die feit dat, soos ek dit toe gesien het, die Nasionale Party onder Vorster met die wysiging van die sportbeleid, die eerste stap geneem het om Verwoerd se beleid te vernietig. In hierdie opvatting het ek nie alleen gestaan nie en lang gesprekke met manne soos ds A J G Oosthuizen, prof H P Wolmarans, dr Piet Meyer (toe voorsitter van die Afrikaner Broederbond) en dan veral met dr Albert Hertzog en mnr Jaap Marais het my oortuig dat Hertzog reg was en Vorster verkeerd en dat die enigste eerbare manier was om 'n nuwe politieke party te stig op die grondslae van Verwoerd se beleid. Of dit meer vrugte sou afgewerp het om binne die Nasionale Party en die Afrikaner Broederbond te bly en daarvandaan die verset te monster, weet ek nie. Die feite van die saak was egter dat die Herstigte Nasionale Party nie daarin kon slaag om 'n beduidende skeuring te bewerk nie en die mag van die Nasionale Party, gerugsteun deur die Afrikaner Broederbond wat na aanvanklike huiwering tog 'n duidelike politieke keuse gemaak en Vorster gesteun het, en die FAK tesame met die Afrikaanse koerante en die radio, het die Herstigte Nasionale Party in die verkiesing van 1970 verpletterend verslaan. Ek het in Waterklonf 
kiesafdeling gewerk vir prof P F D Weiss se verkiesing, maar ons twee taamlik polities onbeholpe akademici, kon nie hond haaraf maak nie hoewel Weiss darem so 'n 900 stemme gekry het. Na 1970 het Vorster, deur middel van die Veiligheidspolisie die Herstigte Nasionale Party voortdurend gemonitor en ons telkens uitoorlê omdat hy so presies geweet het wat die Herstigte Nasionale Party beplan het.

Ek het egter by die Herstigte Nasionale Party gestaan omdat dit vir my om ' $n$ beginsel gegaan het, naamlik dat die Verwoerd-Herstigte Nasionale Party-beleid, histories gesproke, in die lyn gelê het wat ons Kerk steeds gevolg het, onder andere met ons volkskerklike sendingbenadering wat so anders is as die Engelse en ook NG-benadering wat almal in die sendende kerk wil opneem.

In dié tyd het dit my opgeval hoe die predikante hulle laat saamsleep het deur die Afrikaanse koerante en radio en Vorster se argumente. My politieke keuse het, indien moontlik, my in die Kerk en op die kerklike vergaderings nog meer omstrede gemaak. Terloops: nou se dae, in die era van De Klerk, waar die konsekwensies van Vorster se keuse na links getrek word, is dit duidelik dat die Herstigte Nasionale Party in 1969 reg was, maar nie in staat was om met die middele tot sy beskikking, die aandag van die Afrikaners te kry nie.

My 'omstredenheid' het meegebring dat die Algemene Kerkvergadering in 1976 besluit het dat dienaars van die Woord glad nie aan die party-politiek mag deelneem nie. Ek is nou nog oortuig daarvan dat dié besluit uitsluitlik geneem is omdat ek kort vantevore as 'n amptelike HNP-kandidaat vir die Stadsraad van Pretoria gestaan het. Daarby was ek op daardie stadium een van die twee onder-voorsitters van die Party.

Die feit dat ek in 1973 uit die Broederbond geskors is...het seker ook daartoe bygedra dat ek vir baie van die predikante-kollegas 'n verleentheid geword het...Na die Algemene Kerkvergadering het dit nog stiller in die Kerk rondom my geword...'n Klein groepie jonger predikante het hulle in daardie tyd om my geskaar en saam met Albert llerbst en 'n paar ander manne aan my vriendskap en geselskap verleen. Op die ou end was dit nogal 'n interessante waterskeiding wat rondom my persoon plaasgevind het in die sewentigerjare. Een ding het daardie tyd my geleer en dit is dat alleen getoetste vriendskap die moeite werd is. 


\section{Vanaf die sewentigerjare}

Vanaf die vroeë sewentigerjare het ek al meer en meer my eie pad geloop. Die feit dat die Kommissie van die Algemene Kerkvergadering my, na die lastersaak wat ek verloor het in 1967, gehandhaaf het as hoogleraar, het my laat besluit dat ek my werk so moet doen dat die Kerk daarvan voordeel en nie nadeel sal hé nie. Daarby het ek ook tot die gevolgtrekking gekom dat ek deur navorsing en publikasie die Kerk miskien die beste kan dien en daarom het ek my daarop toegespits. Juis omdat ek nie meer populer was nie, kon ek my in my studeerkamer terugtrek en voortgegaan met studie, navorsing en publikasie.

Hoewel ek na die besluit van die Algemene Kerkvergadering in 1976 my posisies in die Herstigte Nasionale Party moes prysgee, het ek tog nog voortgegaan om my goeie vriend, Beaumont Schoeman, die redakteur van Die Afrikaner, by te staan deur weekliks 'n 'godsdiens'-artikel vir sy blad te skrywe. Dit het gelukkig geen ergernis in die Kerk veroorsaak nie omdat die meeste mense in die Kerk nie Die Afrikaner gelees het nie. Ek het redelik lank met die weeklikse bydrae volgehou en later, van tyd tot tyd, wanneer daarvoor gevra, ' $n$ bydrae geskryf.

(Pont 1990:14)

\section{AKADEMIESE EN TEOLOGIESE WERK}

Aangesien dr J J Steenkamp in 'n ander uitgawe van die Henormde Teologiese Studies uitgebreid handel oor Pont se akademiese en teologiese werk, gee ons hier baie kursories daaraan aandag.

Vanaf die Cottesloebyeenkoms in 1960 het prof Pont wye en diepgaande navorsing gedoen oor die Wèreldraad van Kerke, die liberalisme en kommunisme en die rol van die internasionale geldmag. Sy studie- en leeswerk loop onder andere uit op 'n verslag saam met wyle dr $\mathbf{C} \mathbf{J}$ Mans oor die Christelike Instituut. Dié verslag is later deur die Kerk aan die Schlebuschkommissie voorgele. Sy studie op dié terrein loop ook uit op proefskrifte deur R Sauerzapf, J J Steenkamp en J P Labuschagne. Dié van Sauerzapf was die eerste proefskrif van 'n buitelander wat aan die Fakulteit Teologie (Afd A) aan die Universiteit van Pretoria ingedien is.

Op die gebied van die Kerkreg het Pont se studie uitgemond in 'n omvattende werk oor die historiese agtergronde van die kerklike reg. Dié boek word wyd in 
Suid-Afrika gebruik. Een proefskrif, naamlik dié van B J van Wyk, is op dié terrein onder leiding van professor Pont voltooi.

Ten opsigte van die Algemene Kerkgeskiedenis het Pont sy studie veral op die sestiende eeu toegespits. Hy het 'n sterk rol gespeel in verskeie internasionale sowel as Suid-Afrikaanse Calvynkongresse. Uitgebreide lesingaantekeninge oor die sestiende-eeuse reformatoriese kerkgeskiedenis, die Nederlandse Kerkgeskiedenis asook 'n publikasie oor Luther getuig van uitmuntende akademiese kwaliteit.

Van Pont se vrugbaarste en invloedrykste akademiese werk is egter gelewer op die terrein van die Suid-Afrikaanse Kerkgeskiedenis. Hier het hy sy navorsing toegespits op die wordingsgeskiedenis van die Nederduitsch Hervormde Kerk. Vier proefskrifte is op dié terrein onder sy leiding voltooi, naamlik dié van $\mathbf{S} \mathrm{J}$ Botha, J M G Storm, S P Pretorius en H J Botes.

Wat Pont se teologie betref, word die aandag hier op net een uitstaande faset toegespits en dit is sy teologiese deurdenking van die inhoud en drakrag wat die begrippe verbond', 'volkskerk', 'gemeenskap', 'kerk', volk' en 'owerheid' vir die Voortrekkers in die vorming van hulle eie gemenebes in die Over-Vaalse gebied gehad het.

Pont self sou as verbondsteoloog getipeer kon word. Uitgaande van die Reformasie, die situasie in Nederland teen die middel van die sewentiende eeu en die Voortrekkers se opvattings soos dit veral vanuit die Ou Testament en ook deur die oude schrijvers soos veral à Brakel gevorm is, kom hy tot die konklusie dat die mislukking van die kerkvereniging in 1885 in werklikheid 'n mislukte poging was om twee botsende opvattings oor gemeenskap, volk en kerk met mekaar te versoen (Pont 1986:29).

Met sy studie van dié opvattinge van die Voortrekkers en veral die invloed van die oude schrijvers het Pont baanbrekerswerk verrig. Hy toon aan hoe die opvatting oor die volkskerk vanuit die sestiende-eeuse teologie en die teologies-bepaalde opvattings oor volk, gemeenskap en kerk gegroei het. In Nederland van 1651 was daar 'n organiese eenheid gesien tussen gedoopte volk, kerk en owerheid. Die basis van dié denke is dat die hele volk, kragtens die doop, deel is of vormgewing is van die verbond. Tydens die Kompanjiesbewind aan die Kaap is die opvattinge daarheen oorgedra. Kerk en volk was prakties een en die gedoopte volk is regeer deur 'n Christelike owerheid. Die Calvinistiese opvattings oor die genadeverbond soos dit veral in die werk van a Brakel bekendheid verwerf het, het groot invloed op die Voortrekkers se gebruik van die begrippe volk', 'kerk' en 'owerheid' uitgeoefen.

Samevattend ten opsigte van die Voortrekkers se vormgewing van hulle gemenebes of maatskappy, kan gestel word dat die visie van die Calvinistiese teokrasie waar die Ou Testament paradigmaties gelees 
en verstaan is, grotendeels hulle denke beheers het. Dit het meegebring dat die struktuur van die genadeverbond en wat daarmee saamgehang het, ' $n$ sentrale plek in hulle denke ingeneem het. Die genadeverbond wat die basis van hulle kerkbegrip was, het meegebring dat hulle die samehang van kerk-volk-owerheid in die sin van Artikel 36 NGB gesien het. Juis omdat kerk en volk by die Voortrekkers dieselfde was, was die organiese eenheid van kerk-volk-owerheid, soos dit gevind word in die Gereformeerde kerkstaat wat in 1651 in Nederland gevestig is, byna vanselfsprekend. Daarom kan gesê word dat met die saamval van kerk en volk in die Voortrekkerrepubliek dit vir die Voortrekkers grotendeels vanselfsprekend was dat die owerheid van die gedoopte volk, 'n Christelike owerheid sou wees wat as rigsnoer vir sy handelinge Skrif èn belydenis sou hê.

(Pont 1986:59)

By dié verbondsteologie van die Voortrekkers vind Pont in sy eie teologiese denke sterk aansluiting.

\section{KERKLIKE BEDRYWIGHEDE, OPENBARE LIGGAME EN TOEKEN- NINGS}

Professor Pont het tydens sy professoraat in verskillende gemeentes as pastorale hulp dienswerk verrig, onder andere in Melville vir ses maande in 1962, Wespark in Pretoria vir die periode 1966-1972 en in Otjiwarongo (SWA) 1972/1973-1988. Daarbenewens het hy 'n enorme aantal Ringsvergaderings, Ouderlingvergaderings en ander kerklike byeenkomste oor kerklike, kerkregtelike en historiese sake toegespreek.

Hy het onder andere op die volgende kerklike liggame gedien:

- Raad vir Argief en Museum: as lid vanaf 1957 en as voorsitter vanaf 1960:

- Raad vir Regsadvies 1961-1983: vir baie jare as voorsitter;

- Kommissie van die Algemene Kerkvergadering: as predikantslid (sekundus vir dr C J Mans wat in 1974 oorlede is) 1974-1976; as verkose predikantslid 19831989; as onder-voorsitter 1989 tot Januarie 1992;

- Raad vir Belydenis- en Liturgiese Geskrifte 1957 tot vandag. 
Prof Pont het tydens sy loopbaan ook onder andere op die volgende openbare liggame gedien:

- Die Nasionale Raad teen Kommunisme 1964-1970;

- Aanvanklik sekretaris en later voorsitter van die Kerkhistoriese Genootskap van die Nederduitsch Hervormde Kerk van Afrika, vanaf 1958 tot hede;

- Voorsitter van die Suid-Afrikaanse Kongres vir Calvynnavorsing van 1980 tot hede;

- Redaksielid van die $H T S$;

- Stigterslid en ondervoorsitter van die Afrikanervolkswag van 1984 tot hede;

* Lid van SABRA.

Toekennings ontvang:

* Die SP Engelbrecht Erepenning vir Kerkgeskiedskrywing (goud) in 1957: toegeken deur die Fakulteit Teologie;

* Die H C M Fourie Erepenning (goud) in 1986: toegeken deur die Kuratorium vir die Teologiese Opleiding van die Nederduitsch Hervormde Kerk van Afrika.

\section{GESINSLEWE}

Naas sy sterk betrokkenheid in teologie, kerk, politiek en kultuur, was daar steeds in professor Pont se lewe ook die ander baie sterk anker: sy huwelik en gesin. Vanuit die kern en kragbron van 'n gesonde gesin het hy sy werk verrig en was altyd 'n toonbeeld van geloofskrag en vertroue.

Hy is op 12 April 1958 getroud met Leonie Jansen van Vuuren, 'n nooi uit Heilbron se wêreld. Sy is die oudste dogter van Daniel Christoffel Lourens Jansen van Vuuren (5 Junie 1900 - 12 Augustus 1972) en Johanna Isabella Leonard (4 Desember 1909).

Sy vrou se oupa, Daniel Christoffel Lourens Jansen van Vuuren (3 Julie 1863 $31 \mathrm{Mei}$ 1942) het in die Vereeniging-kommando en later onder die bevel van generaal J C Smuts in die Engelse Oorlog van 1899-1902 geveg. Hy was 'n bittereinder. Sy vader, Lucas Gerhardus Jansen van Vuuren (17 Junie 1819 - Julie 1912) was 'n Voortrekker wat in die Slag van Bloedrivier geveg het.

Die Van Vuurens was Potchefstroomse Hervormers. Mev Pont se oupa is deur ds Van der Hoff gedoop. Hulle het in 1885 verenig en daarna in die Verenigde Kerk gebly.

Uit die huwelik is gebore:

* Johan Willem op 5 Oktober 1959, getroud met Ilze van Rensburg op 8 September 1990; 
- Isabel Leonora op 8 Junie 1962, getroud met Werner Abraham Erasmus op 3 Desember 1983;

- Jeanne Louise op 21 Januarie 1965;

- Daniel Christoffel Lourens op 15 Oktober 1967;

- Adri Leonie op 11 Januarie 1976.

\section{3. 'N WAARDERING}

'n Vol, ryk-geskakeerde lewe: So sou 'n mens die lewe van prof Adriaan Pont wou opsom. Met die woorde wat hier volg, wil gepoog word om die liefde, toegeneëntheid en waardering van baie mense wat rondom hom geleef het, te vertolk.

Die skrywer van hierdie artikel wil hom bedank vir sy integriteit en lojaliteit as vise-voorsitter van die Kommissie van die Algemene Kerkvergadering die afgelope drie jaar. Die opregtheid waarmee hy bereid was om as vise-voorsitter hom te skik onder die leiding van 'n veel jonger man as voorsitter sal altyd onthou word. In die lewe van Adriaan Pont is daar nie ruimte vir die kleinlike nie. Sy adviese as kenner van die Kerkreg was vir die Kommissie goud werd en sal gemis word.

As hoogleraar in die Kerkgeskiedenis en Kerkreg het hy sy teologie beoefen vanuit die bodem van die Bybelse Reformatoriese teologie. Daarvan is hy deurdrenk. Ander bronne en uitgangspunte ken hy nie en kon hy altyd met ongeërgdheid by hom laat verbygaan.

In sy prediking was daar net een tema: God, sy dade en heil vir mense. Die verhouding tussen God en mens rus op net een basis: die verbond. Dat, te midde van soveel moderner, subjektiewe strominge in die teologie, die Nederduitsch Hervormde Kerk die krag van dié eensydigheid in die Fakulteit Teologie (Afd A) sal moet ontbeer, stem tot kommer. Vir die subjektiewe, emosionele en dweperige in teologie en kerk kon hy eenvoudig nooit aptyt ontwikkel nie.

As akademikus en mens is Adriaan Pont 'n netjiese en gedissiplineerde mens: in kleredrag, handskrif en die absoluut stiptelike afhandeling van opdragte. Hy is 'n vriendelike man met 'n fyn humorsin. Soos alle jagters beskik hy oor 'n eindelose, onuitputbare bron van stories en grappe!

$\mathrm{Hy}$ is in die volle sin van die woord ' $\mathrm{n}$ reformatoriese teoloog, kerkman en volksman. Sy onbuigsaamheid op al dié terreine het daartoe gelei dat hy nie altyd by almal populêr was nie. Sy geskrewe adviese en rapporte aan die Hervormde Kerk, dogmenhistories en kerkregtelik deeglik verantwoord, is van onskatbare waarde. As onvermoeide student sal hy die Hervormde Kerk op dié terrein bly dien. As hy dalk later nie meer kan nie, sal die kerk eers reg besef wat hy gehad het, veral in krisistye, aan hierdie gelowige, standvastige, positiewe, altyd opgewekte mens. 
Professor Pont is, veral as skrywer, geneig om aggressief, selfs moedswillig te wees. Hy het altyd met homself moeite as hy die liberales, wat hy sien as bedreiging vir kerk en volk, aanvat. Maar belangriker as dit is die feit dat hy besef en erken dat hy ook foute gemaak het.

Hy het hoogte- en laagtepunte geken. Rondom sy persoon het soms emstige konflik en onmin gewoed. Hy maak melding van seer wat hy aangedoen is. Maar baie belangriker as dié verwyt, is dat hy raakgesien het dat die Hervormde Kerk ook teenoor hom met groot liefde en geduld opgetree het. Daarom is daar by hom by emeritaat-aanvaarding geen verbittering nie. Daarvoor is ons dankbaar.

Familie, vriende, kollegas, studente, die hele Hervormde Kerk betuig dank aan hierdie man vir sy werk en toewyding. Dank aan God vir soveel gawes wat Hy deur mense gee. Seën toegewens vir die pad verder. Ons is met nostalgie vervul. Saam met prof J P Oberholzer is A D Pont die laaste van 'n groep wat die Hervormde Kerk uitnemend gedien het.

\section{PUBLIKASIES}

\subsection{Boeke}

Nicolaas Jacobus van Warmelo, 1835-1892, Utrecht 1952 (proefskrif).

Die Nederduitsch Hervormde Gemeente Waterber, 1865-1965, Krugersdorp 1965.

Die Nederduitsch Hervormde Gemeense Heidelberg, 1865-1965, Krugersdorp 1965.

Die oudste kerkgebou in Transvaal: lets oor die geskiedenis van die kerkgebou van die NH Gemeente Potchefstroom, 1866-1966, Krugersdorp 1966.

'n Oorsig van die Algemene Kerkgeskiedenis en die geskiedenis van die Nederduitsch Henormde Kerk van Afrika: Opgestel ten dienste van die kategese van die kerk, Krugersdorp 1966 (eerste druk). Tweede druk 1970, derde druk 1978.

Die historiese agtengronde van ons kerklike reg, deel 1. Pretoria 1981.

Man van die Woord: 'n Lewenskets van Martin Luther. Pretoria 1984.

Die historiese agtergronde van ons kerklike reg, deel 2. Pretoria 1991.

As medeskrywer saam met B Spoelstra en B R Keet, Kerkgeskiedenis Std 9, Pretoria ens 1973.

As redakteur: Die Ned Henormde Gemeente Pretoria 1855-1980: Enkele grepe uit die geskiedenis, Pretoria 1980.

As redakteur: Gedenkalbum 1886-1986 van die Nederduitsch Hervormde Kerk van Afrika in woond en beeld, Pretoria 1986. 


\subsection{Brosjures}

Die boodskap van Geloftedag, Pretoria 1973.

Sensitiwiteitsopleiding, Pretoria 1973.

Opsig en tug, Pretoria 1975.

Die liberalisme in die Afrikaanse kerke, Pretoria 1978.

Die amp in die kerk, Pretorla 1979.

Heidelberg: Vyftigjarige gedenkalbum van die kerkgebou, 1933-1983, Pretoria 1983.

\section{Artikels in verskillende publikasies}

Die geskiedenis van die Afrikaanse kerke in die Suid-Afrikaanse historiografie, artikel in G Cronje (red), Aspekte van die Suid-Afrikaanse historiografie, Pretoria 1967, bl 40-57.

In Die Suid-Afrikaanse biografiese woordeboek: N J van Warmelo, D van der Hoff, J van Belkum, G J Engelbrecht, S P Engelbrecht.

Ds M J Goddefroy 1848 - 1920, artikel in J J P Müller (red), Die Nederduitsch Hervormde Gemeente Bronkhorstspruit 1869-1969, Krugersdorp 1969, bl 140-170.

Die reg van opstand by Thomas Münzer, artikel in Tydskrif vir Geesteswetenskappe, Jrg 14, 1974, bl 16-32.

Die ouderling en die opsig en die tug, artikel in J H Koekemoer (red), Handleiding vir ouderlinge, Pretoria 1979, bl 68-82.

Die Psalmzingers, artikel in J A Loader (red), 'n Nuwe lied vir die Here: Opstelle by die verskyning van die nuwe Afrikaanse Psalm- en Gesangboek, Pretoria-Kaapstad 1979, bl 67-75.

Vyftien korter en langer artikels in Afrikaanse kultuuralmanak, Johannesburg 1980.

Die stigting van die Gemeente Pretoria, artikel in A D Pont (red), Die Nederduitsch Hervormde Gemeente Pretoria 1855-1980: Enkele grepe uit die geskiedenis, Pretoria 1980 , bl 1-5, 29-36.

Soek in die verlede: Geestelike toerusting in die stryd om selfbehoud, artikel in Tydskrif vir Rasse-Aangeleenthede, Jrg 36, nr 2/3, bl 58-63. 
Die Gelofte in gedrang, art in F J Strauss en A D Pont (red), Bloedrivier: Stem uit die verlede, taak vir hede, hoop vir die toekoms, Windhoek 1986, bl 16-23.

Oorsprong van die Israel-visie: Waarheid en verbeelding, artikel in $\mathbf{H} \mathbf{G}$ van der Westhuizen (red), Blankheid en waarheid, Pretoria 1989.

Die amp as dienswerk in die kerk, artikel in J A du Rand en J S Kellerman (red), Diensknegte van die koning: Huldigingsbundel ter ere van prof $J J$ de Klerk en prof $E J P$ Kleynhans, Bloemfontein 1989.

Die Gelofte van 1838. 'n Poging om die teologiese agtergronde te peil, artikel in A D Pont (red), Die Gelofte van 1838: Historiese gebeure en verpligtende werklikheid, Pretoria 1988.

Die kerk as volkskerk, artikel in Die Bondsgeruie, Jrg 3 1/2, Pretoria 1990, bl 16-23.

Piëtisme en sy implikasies op sosiale fronte, Studia Historiae Ecclesiaoticae, Vol VIII, 1982.

\subsection{Wetenskaplike artikels in Henormde Teologiese Studies} Jaargang

11: Enkele trekke uit die vroomheid van Jodocus van Lodenstein, bl 18-33.

12: Enkele inleidende opmerkings oor 'liturgie' vanuit reformatoriese standpunt, bl 57-67.

13: Die geskiedenis van die Christendom, bl 2-8.

14: Enkele aantekeninge by die teologies-godsdienstige gedagtes van sendeling $\mathbf{S} \mathbf{J}$ G Hofmeyr 1839-1905, bl 159-176.

15: Enkele aantekeninge by die debat oor die uitleg van die Dordtse Leerreëls wat in $\mathbf{1 8 7 1}$ deur ds $\mathbf{J} \mathbf{J}$ Kotze van Darling en ds Andrew Murray gevoer is, bl 29 38 .

16: 'n Ontleding van die teologies-dogmatiese agtergrond van ds S D Venter se afskeiding van die Gereformeerde Kerk in die OVS, bl 89-105.

16: Herdenking van die Hervorming, bl 314-329.

17: Die Kerkwet en die amp van dienaar van die Woord, bl 66-83.

18: Enkele opmerkings oor objektiewe kerkgeskiedskrywing, bl 146-153.

19: Die Kerkwet van 1862, bl 36-47.

19: Oor die tweede Vatikaankonsilie, bl 65-81. 
20: 'n Dogmenhistoriese skets van die leer van die algemene priesterskap van die gelowiges, bl 1-10.

20: Die vestiging van die Nederduitsch Hervormde Kerk in 1853 en die eerste afskeiding van Lydenburg in 1854: Kerkregtelike implikasies, bl 149-161.

21: Die boodskap van Luther se 95 stellings, bl 89-101.

22: Vyftig jaar geskiedenis van die Christendom aan die Teologiese Fakulteit Afdeling A van die Universiteit van Pretoria 1917-1967, bl 163-176.

23: Gister, vandag en môre, bl 63-75.

24: Sekularisasie: Historiese en kerkhistoriese faktore wat tot die hedendaagse situasie gelei het, bl 128-141.

24: The University Christian Movement.

25: Die groot sinode van Dordrecht 1618-1619, bl 74-87.

25: Kerk en volk, bl 202-218.

26: Die vermindering van die ledetal van die Algemene Kerkvergadering, bl 118145.

27: Aantekeninge rondom die ampsopdrag van die diaken, bl 8-46.

28: Tydelik-deeltydse predikante, bl 97-117.

28: Die kerkorde van Emden 1571, bl 148-159.

29: Opmerkings oor die Covenant-gedagte by John Knox en die Skotse reformasie, bl 48-60.

29: Black Theology: Voorbereiding vir die rewolusie, bl 62-79.

29: Opmerkings oor 'n Teologie van Strukture, bl 95-115.

30: Rondom die figuur van ds Dirk van der Hoff, bl 163-182.

31: Kerkgeskiedenis as 'n begrip tydens die Kerkhervorming, bl 38-54.

32: Kerk en keiser by Nicea, bl 20-32.

32: Amp en roeping, bl 168-180.

33: Skrif en kerkorde, bl 77-90.

33: Was die optrede van die Konsulentsgemeente Pretoria in 1885 'kerkskeurend?', bl 27-40.

34: Waar begin en waar eindig die amp?, bl 48-58.

34: Die Herderlijken Brief van die sinode van 1837, bl 91-105.

35: Die Calvinisme vandag, bl 1-10.

35: Dwalings rondom die Heilige Gees, bl 76-86.

37: Die figuur van Van Broekhuizen: Uit die geskiedenis van die gemeente Pretoria, bl 55-73.

38: Kerk en struktuur, bl 1-22.

38: Wat hoort tuis in 'n kerkwet of kerkorde in die lig van Skrif en belydenis?, bl 23-35. 
39: Vyf en twintig jaar kerkreg binne die ruimte van die Nederduitsch Hervormde Kerk van Afrika, bl 18-31.

40: Rondom die begrafnisdiens, bl 111-122.

40: Die invloed wat Calvyn uitgeoefen het op die samestelling van die eerste kerkordes van die Franse, Skotse en Nederlandse kerke gedurende die sestiende eeu, bl 120-134.

41: Die Nederduitsch Hervormde Kerk se profetiese verantwoordelikheid teenoor die owerheid in die verlede en vandag, bl 29-48.

41: Thomas Erastus oor die struktuur van die gemeenskap, bl 428-440.

42: Verbond en volkskerk, bl 28-76.

42: Calvyn en die kerklike orde: Enkele opmerkings, bl 534-546.

43: Die vrye kerk: Enkele opmerkings oor die herkoms en inhoud van die opvatting, bl 24-46.

43: Die betekenis van Abraham Kuyper (1837-1920) vir Suid-Afrika op kerk-historiese en kerkregtelike gebied, bl 506-521.

44: Die sekerheid van die geloof by Calvyn en sommige van sy navolgers, bl 404419.

45: Die priesterskap van die gelowiges soos Calvyn dit gesien het, bl 451-460.

45: Die Groot Trek en die kerk, bl 655-670.

46: Dirk van der Hoff: Skeurmaker? (mede-outeur), bl 414-427.

47: Kategese, kategismusse en die belydenis van geloof in Genève in die dae van Calvyn, bl 431-441.

47: Die verhouding 'kerk en volk' in die jare 1835-1900 in die Oorvaalse: 'n Terreinverkenning, 783-799.

\subsection{Artikels in Die Hervormer}

1956

Oktober : Die Bybel en die kerhervorming.

Gaspard du Chatillon, Graaf de Coligny 1517-1572.

1957

Oktoher : Geregverdig deur die geloof (Oordenking).

Die Hervorming - her-vorming of afskeiding?

1958

: Die kontrovers tussen prof Engelbrecht en dr G D Scholtz oor die kerkgeskiedenis 
1959

Februarie : Artikel III, kerkregtelik gesien.

Mei : Die geskiedenis van die Franse protestantisme tot 1798.

Julie : Ds Jac van Belkum.

Belangrike skenking aan die Kerkargief en Museum.

Oktober : Hoeksteenlegging van die nuwe Dirk van der Hoffgebou.

1960

Januarie : Kommentaar by 'n radioberig.

Mei : John Knox 1513-1572: 'n Lewenskets van die hervormer van Skotland.

1961

Oktober : Guido de Bray: 'n Biografiese skets.

1962

Februarie : Die Wêreldraad van Kerke en die wêreld. Johannes Calvyn, 'n lewenskets.

Maart : Maarten Luther, 'n lewenskets 1.

April : Maarten Luther, 'n lewenskets 2.

1963

Januarie : lets oor die ontstaan van die Heidelbergse Kategismus.

1964

Januarie : Kroniek : Die Sondagkwessie.

Die kerk en die kommuniste.

Februarie : Kroniek : Die taak van die teologie.

Die Algemene Kerkvergadering en die sending.

Maart : Kroniek : Bekommernis oor die Afrikaanse kerke.

Oor die Christelike Instituut.

Die Afrikastate noord van ons.

April $\quad$ : Kroniek $\quad$ : Aartsbiskop W P Whelan.

Prinses Irene van die Nederlande. 
Die komende Algemene Kerkvergadering.

Rondom die kerklike reorganisasie.

Mei : Kroniek : Die Volkskongres oor kommunisme.

Die reaksie van die Metodistekerk.

Die harwar te Balfour.

Junie : Kroniek : Oor die Algemene Kerkvergadering 1964.

Die slot van die Geyser-episode.

Die wins van die Algemene Kerkvergadering.

Skeurmakery.

Julie : Kroniek : Vakansiemaand.

Die Katolieke Afrikanersentrum.

Oor die Presbiteriane.

- Die Nederduitse Gereformeerde Kerk en die Christian Council.

Augustus : Kroniek : Bestryding van die kommunisme.

'n Roomse aanval op die kerk.

Die Christendom en die Jodedom.

Die Predikantevergadering van die Nederduitsch Hervormde Kerk van Afrika.

September : Kroniek : Rondom die Ekumene.

Oor die Wêreldraad van Kerke.

Die DRC en die Presbiteriane.

Okıober : Kroniek : Herdenking van die Kerkhervorming.

Die Wêreldraad van Kerke en die godloses.

Infiltrasiepogings van die Wêreldraad van Kerke in ons land.

Hervormd Nederland.

November : Kroniek : Die Nederduitsch Hervormde Gemeente Windhoek.

Andermaal oor die Wêreldraad van Kerke. 
Die Wêreldraad van Kerke, die kommunisme en ons Afrikaanse kerke.

Desember : Kroniek : Uittrede van ds en mev A J G Oosthuizen.

Newscheck oor die Afrikaanse kerke.

'n Christian Council in Pretoria?

1965

Januarie : Kroniek : Die Wêreldraad van Kerke en SA-Kitwe 1964.

Oor die Social Gospel.

Die jaar 1965.

Februarie : Kroniek : Die Wêreldraad van Kerke in Afrika.

Oor die Christelike Instituut.

Maart : Kroniek : Die NZAW.

Beplanning vir rewolusie.

Immigrante en Engelse kerke.

Predikantetekort.

: Artikel : Opmerkings oor Christelike feeste.

April $\quad:$ Kroniek $\quad$ : Christene wat die Christendom haat.

Nogmaals die Social Gospel.

'n Stem uit Nederland.

Die NHSV - 25 jaar.

Mei : Kroniek : Oor die droogte.

Pro Veritate en die kommunisme.

Merkwaardige uitsprake.

Junie $\quad$ : Kroniek : 'n Beeld van Suid-Afrika.

Die Predikantetekort.

Julie $\quad:$ Kroniek : Die toekoms wat vir ons beplan word.

Die politieke aanslag. 
Die aanval op die gees van die Afrikaner.

Die aanval deur middel van die kommuniste.

: Artikel : Johannes Hus: 'n Lewenskets.

Augustus : Kroniek : Die verhouding van ons Afrikaanse kerke met die Christelike kerke in die buiteland. 'n Christian Resistance Movement.

September : Kroniek : Christelike getuienis.

Die Amerikaanse blad: The Church Herald.

Oktober : Kroniek : Ds Simon Vermooten.

Die Lutherische Monatshefte.

Perspektief.

November : Kroniek : Waterberg 1865-1965.

Martin Luther King.

Oor die vernuwing van die kerk.

Desember : Kroniek : Ramsey en Rhodesië.

Challenge.

Die einde van die jaar.

1966

Januarie : Kroniek : Rhodesiese onafhanklikheid.

Rhodesiese onafhanklikheid en die kerke.

Rhodesiese onafhanklikheid en die Afrikaner.

Artikel : Enkele opmerkings rondom die eeufeesviering van die Gemeente Kaapstad.

Februarie : Kroniek : Oor die linkse sameswering teen die blanke. Kerkvereniging tussen die Anglikane en Presbiteriane.

Maart : Kroniek : Nog 'n Instituut?

Geloftedag op Wilgespruit. 


\begin{tabular}{|c|c|c|c|c|}
\hline & & & & $\begin{array}{l}\text { Die Wêreldraad van Kerke in Afrika. } \\
\text { Andermaal die ARM. }\end{array}$ \\
\hline April & : & Kroniek & : & $\begin{array}{l}\text { Rondom die Teologiese Fakulteit. } \\
\text { Trekarbeid. } \\
\text { Maj E C Bundy van Amerika. }\end{array}$ \\
\hline Mei & : & Kroniek & : & $\begin{array}{l}\text { Nuwe sekretaris van die Wêreldraad van K } \\
\text { Die Wèreldraad van Kerke en Rhodesië. }\end{array}$ \\
\hline Junie & : & Kroniek & : & $\begin{array}{l}\text { Die Republiekfees. } \\
\text { Die VVO en SA. }\end{array}$ \\
\hline Julie & : & Kroniek & : & $\begin{array}{l}\text { Republiekfees: Nabetragting. } \\
\text { Internasionale simposium oor kommunism } \\
\text { Windhoek, SWA. }\end{array}$ \\
\hline Augustus & $:$ & Kroniek & : & $\begin{array}{l}\text { Biskop James P Dees. } \\
\text { Beroeringe in die Engelstalige kerke. }\end{array}$ \\
\hline September & $:$ & Kroniek & : & $\begin{array}{l}\text { Die hedendaagse Genève. } \\
\text { Integrasie - 'n geloofsbelydenis? } \\
\text { Die SWA-saak. }\end{array}$ \\
\hline Oktober & : & Kroniek & : & $\begin{array}{l}\text { Dr H F Verwoerd 1901-1966. } \\
\text { Spel met woorde. } \\
\text { Die TRUK-opvoering: The devils. }\end{array}$ \\
\hline November & : & Kroniek & : & $\begin{array}{l}\text { Die Internasionale Simposium teen Kom- } \\
\text { munisme. } \\
\text { Die getuienis van pastor R Wurmbrand. } \\
\text { Die WRK-konferensie in Genève. }\end{array}$ \\
\hline Desember & : & Kroniek & : & $\begin{array}{l}\text { Desembermaand. } \\
\text { Rondom die CISA. } \\
\text { Die kerk in Rusland. } \\
\text { Opslae in Holland. } \\
\text { Prof Maarten van Rhijn. }\end{array}$ \\
\hline
\end{tabular}


1967

Januarie : Kroniek : Die Nederlandse Hervormde Kerk, die CISA en die Nederduitse Gereformeerde Kerk.

'n Verkeerde tendens?

Die jaar wat voorlê.

Februarie : Kroniek : Kommunistiese beplanning.

Maart : Kroniek : Die Algemene Kerkvergadering.

Die Teologiese Fakulteit vyftig jaar oud.

April : Kroniek : Die Algemene Kerkvergadering.

Mei $\quad:$ Kroniek : Pous Paulus VI en social justice.

Junie : Kroniek $\quad$ : Oor die Wêreldraad van Kerke.

Kerk en gemeenskap volgens die Wêreldraad van Kerke.

Die Algemene Kerkvergadering 1967.

Julie : Kroniek : Besluite van die Algemene Kerkvergadering.

Randburg en Witpoortiie.

Die Christelike Kultuuraksie.

Augustus : Kroniek : Die 'teologie' van rewolusie.

September : Kroniek : Die Neger-burgeroorlog in die VSA.

'n Interessante opinie.

Beginsel of dienstigheid.

Oktober : Kroniek : Leertug in Amerika.

Die Roomse kerk in die VSA.

Die begrip 'ras'.

Rhodesië. 
November : Kroniek : Die vervolgde Christendom in die Soedan.

Die Neger-burgeroorlog in die VSA.

Die Metodiste van die VSA.

Artikel : Reformasie en rewolusie.

Desember : Kroniek : Desember.

W Ellioth, woordvoerder van die NCCC van die VSA.

Die Wèreldraad van Kerke.

1968

Januarie : Kroniek : Verset teen die bestaande orde.

Februarie : Kroniek : Prof J I de Wet.

The Church Herald.

Joost de Blank.

Die Predikantetekort.

Maart : Kroniek : Die CCIA en die rassevraagstuk.

'n Opmerking oor die liberalisme.

April $\quad$ : Kroniek : Géén Kroniek het die maand verskyn nie.

Mei : Kroniek : Opmerking.

Ex-biskop Crowther.

Challenge en die Liberalisme.

Junie $\quad$ : Kroniek : Die wiel draai.

Steun vir terrorisme.

Geloftefeeste.

Julie $\quad:$ Kroniek : 'n Stem uit die verlede.

Die kerk en rewolusie.

Augustus : Kroniek : Christendom en rewolusie.

Artikel : By die herdenking van die Bartholomeusnagbloedbad 1572. 
September : Kroniek : 'n Kerklike kapitulasie.

One for the road.

Oktober : Kroniek : Blanke en Bantoe.

'n Ander geluid.

Artikel : Die Kerkhervorming van die sestiende eeu.

November : Kroniek : Die Wêreldraad van Kerke.

Geweld.

In memoriam.

Artikel : Rondom die Sinode van Dordrecht 1618-1968.

Desember : Kroniek : Desembermaand.

'n Heilige Oorlog word verklaar.

1969

Januarie : Kroniek : Dr Daan Booysen

Die Heilige Oorlog voortgesit.

Opmerkings in Woord en Daad.

Februarie : Kroniek : Majubadag.

Maart : Kroniek : Die Anglikaanse kerk in die VSA.

Kerk in die vuurlinie.

April : Kroniek : Gelofteskuld.

Mei : Kroniek : Leiers van die ekumene in Afrika.

Junie : Kroniek : Oor die Calvinisme.

Christelike terrorisme.

Proefpreke.

Julie : Kroniek : Andermaal die Calvinisme.

Ben Venter en Waterbobbejaan. 
Augustus : Kroniek : Die predikant en die studie van ou tale.

September : Kroniek : Pastor R Wurmbrand.

Die verlede.

Oktober : Kroniek : Hervormingsmaand.

November : Kroniek : Novembermaand.

Kommunistiese gevaar?

'n Nuwe visie?

Desember : Kroniek : Aan die einde van 'n dekade.

Op bl 12 van Die Hervormer maak die redakteur, ds Joh Dreyer, 'n paar opmerkings oor die feit dat prof Pont ophou met die skrywe van die Kroniek. Vir ses jaar lank het hy maandeliks die Kroniek behartig en slegs in April 1968 het daar nie 'n Kroniek van hom verskyn nie.

1973

Januarie : Sensitivity training.

Junie : Rassisme en wat dit beteken.

1974

September : Diskriminasie en rassisme.

1976

April : Die Algemene Kerkvergadering.

Desember : Geloftedag.

1977

: Uitleg van Bepaling 98.1 met betrekking tot die Nagmaal.

: Menseregte.

: Kerkgeskiedenis.

1978

: Politieke propaganda in die kleed van godsdiens. 
1979

Desember : Die Gelofte van 1838 en die Sabbatskarakter van Geloftedag, 1.

1980

Januarie : Die Gelofte van 1838 en die Sabbatskarakter van Geloftedag, 2.

Maart : Meningsverskil oor die naam van die kerk.

1981

Desember : Pole ruk die masker van die kommunisme af.

: Geloftedag 'n baken vir die Afrikaner.

1982

Maart ～: Dr J D Vorster: 'n Kompromislose Afrikaner-kerkleier.

Desember : Die Teologiese Fakulteit en die Ou Letteregebou van UP.

1983

Augustus : In en om die kerk: Kettery deur wie?

September : In en om die kerk: Regte verkondiging.

November : In en om die kerk: Predikante en die politiek.

Desember : Die verborge Christus.

: Katharina von Bora 1499-1552.

1984

Februarie : In en om die kerk: Eenheid en die kerk.

: Die aanddiens.

Mei : Die twee lé 'n hegte grondslag: Ds J van Belkum en prof $S$ P Engelbrecht.

1985

Februarie : 'n Amptelike vertaling van die Bybel?

Junie $\quad:$ Die huwelik. 
Oktober : Die herroeping van die Edik van Nantes.

1986

Januarie : Herdenking van die 1885-gebeure.

Onderwys in SWA.

1986

Februarie : Die Kerkvereniging van 1885: Vereniging of 'n poging tot oorname?

April : Ons inhoud en krag lê nie in uiterlike dinge nie.

: Witfontein-nabetragting.

Augustus : Wie verteenwoordig die afgevaardigdes na 'n meerdere vergadering?

September : Teenstem op 'n meerdere vergadering.

Oktober : Die dienstyd van ouderlinge en diakens.

1987

Maart : In en om die kerk: Gemeentevergadering van ampsdraers en lidmate.

Julie : Daadverkondiging bestaan nie.

September : Vyftigjarige herdenkingsfees in SWA.

Oktober : In en om die kerk: Nuwe Afrikaanse kerk kom na vore.

November : In en om die kerk: Taak van die kerk in die wêreld.

1988

Januarie : Opsig en tug en die probleem van die kerklos of onbetrokke lidmaat.

Februarie : Kerk en universiteit: Hoort die kerk se teologiese opleiding aan 'n universiteit? 
Maart : Prof S P Engelbrecht: So het ek hom geken.

April : Die opstanding van Jesus Christus: Daarsonder is alles tevergeefs.

September : Wêreldoorlog bring krisis in kerk en volk, 1.

Oktober : Wêreldoorlog bring krisis in kerk en volk, 2.

November : Wêreldoorlog bring krisis in kerk en volk, 3.

Desember : Wèreldoorlog bring krisis in kerk en volk, 4.

1990

April : Goeie werke: Moralisme of dankbaarheid?

November : Verdwyn die vrees van God uit ons lewe?

\subsection{Artikels in Konteks}

1990

April : Op pad na 'n beter Europa.

Augustus : Onderwys en opvoeding by Calvyn.

September : N J van Warmelo (gebore op 8 September 1832).

Desember : Rondom Kersfees.

1991

Maart : Die kanselkleed?

April : God zal het ons doen gelukken - Ons teologiese opleiding word 75 jaar oud.

Junie : Die Dorslandtrek.

Julie $\quad: \quad$ Schoemansdal (1848-1867). 
14.7 Artikels in die Almanak

1958 : Prof dr S P Engelbrecht: 'n Woord van hulde.

1959 : Die Nederduitsch Hervormde Gemeente Ermelo.

1961 : 'Het Boek van Gods besluiten': 'n Geloftedagpreek. Die Nederduitsch Hervormde Gemeente Heilbron 1911-1961.

1964 : Die penning geslaan ter herdenking van die Bartolomeusnag 1572.

1965 : Oor die kommunisme en die kommunistiese aanslag op ons land. Oor die kerkhervormer Johannes Calvyn.

1968 : Luther se 95 Stellings, 1517-1967.

1969 : Enkele historiese gegewens oor die amp van die diaken en diakensgelde.

1971 : Die kerk in Noord-Afrika.

1973 : Opmerkings oor die 'Black Theology' in Suid-Afrika.

1978 : Die ontstaan van die drie Afrikaanse kerke: Is dit sondige verskeurdheid of verstaanbare verskeidenheid?

1979 : 'n Stoere Hervormer heengegaan: Tant Hannie Robberts van Otjiwarongo.

1983 : Die Hervormde kerkgeboutjie op Moravia. Die Kerkraad van Humpata in 1926.

1985 : Die Nederduitsch Hervormde Kerk leef voort: Feesrede ter herdenking van die vyftigjarige bestaan van die kerkgebou van Heidelberg, 1933-1983.

1986 : Organisasie, administrasie en ekonomiese bedrywe in en van die kerk in die jare 1950-1985.

1988 : Kerk en owerheid by die Voortrekkers.

1990 : Die diaken en die kerkregering.

1991 : Die kerk in die tyd van die rebellie en die eerste Wêreldoorlog.

14.8 Artikels in ander tydskrifte van die Nederduitsch Hervormde Kerk

Van der Hoff-Jaarblad

1964 : Ds Dirk van der Hoff, bl 28-31; 41.

1973 : Heilige Skrif, belydenis en kerklike Orde, bl 24-28. 
1975 : Kerklike integrasie: Opmerkings oor die besluite van die Gereformeerde Ekumeniese Sinode 1972 en die Algemene Sinode van die Nederduitse Gereformeerde Kerk 1974, bl 38-46.

1976 : Prof dr Ben Engelbrecht - enkele biografiese gegewens, bl 6-8.

HSV-Blad

1979 : Opsig en tug in die kerk, bl 14-16.

Die Christelike Vrou

Die krip - Redaksioneel, Des 1959, bl 1.

Die gevaar van Roomskatolisisme, Jul/Aug 1962, bl 16-20.

Die geopende graf - Oordenking, Apr 1965, bl 2.

Verlede, hede, toekoms, herinnering, herdenking, opdrag, Nov/Des 1965, bl 7-12.

Die aanslag op die jeug, Okt 1975, bl 6-7.

Die vroue in die Vroeë Christelike Kerk, Mrt 1979, bl 3-4.

Die bloedbad in Parjs op St Bartolomeusdag, 24 Aug 1572, Okt 1982, bl 3 en 9.

Besoek aan die Vatikaan, Apr 1985, bl 11.

\section{NHSV Jaarboek}

Voorwoord, 1960-1961, bl 1-2.

Renata van Frankryk, Hertogin van Ferrara: 'n Geloofsheldin uit die tyd van die Hervorming, 1960-196i, bl 38-48.

Opening van NHSV-Kongres, 7 Maart 1961, 1961-1962, bl 22-23.

Die Republiek van Suid-Afrika, 1961-1962, bl 58-59.

Heinrich Bullinger, 1964-1965, bl 22-27.

Oor die Volkskongres oo. kommunisme, 1964-1965, bl 32-37.

Besondere feeste in die gemeentes, 1966-1967, bl 35-36.

Huldigingswoord - Prof dr S P Engelbrecht by die oorhandiging van die SA Akademie se besondere erepenning vir kultuurhistoriese prestasie op Maandag, $1 \mathrm{Mei}$ 1967; 1967-1968, bl 29-30.

Dr Martin Luther King. 1981-1983, bl 11-12. 


\subsection{Joernalistiek}

Leer- en Lewenskwessies in Suid-Afrika

1977 Jaargang 1

Kerk en wêreld vandag, Jrg 1/1 bl 7-10.

Die Nederduitsch Hervormde Kerk van Afrika en die geskiedenis van die Afrikaner. Rede gehou by die herdenking van die 125 -jarige bestaan van die Nederduitsch Hervormde Gemeente Rustenburg 14 Nov 1975, Jrg 1/2, bl 8-15.

Prof dr S P Engelbrecht, 1891-1977: 'n Huldeblyk. Jrg 1/3, bl 1.

Rhodesië en die pad vorentoe. Jrg 1/3, bl 9-13.

1979 Jaargang 3

Die simbool van Kruger. Jrg 3/3, bl 9-17.

$1981 \quad$ Jaargang 5

Kerk en politiek. Jrg 5/2 bl 1-4.

1985 Jaargang 9

God en volk of God en mens? Jrg 9/3, bl 43-50.

1986 Jaargang 10

Kanttekeninge by 'n studiestuk. Jrg 10/1, bl 1-11.

Uit die notule van die Algemene Kerkvergadering, Jrg 10/3, bl 21-22.

1987 Jaargang 11

Opmerkings oor die kerkbegrip. Jrg 11/1, bl 5-9.

Kerk en wêreld 1987. Jrg 11/2, bl 3-9.

1989 Jaargang 12

Die herdenking van die Groot Trek 1938-1988. Jrg 12/2, bl 11-18.

Die beraad van die NG Kerk-familie by Vereeniging. Jrg 12/3, bl 1-22.

Die volkskerk, Jrg 12/4, bl S-24.

1990 Jaargang 13

Die kerk moet kerk bly, Jrg 13/1, bl 16-24.

Kerk en wêreld vandag, Jrg 13/2, bl 2-3. 
Suid-Afrika en die politieke toekoms van die Afrikanervolk: Enkele gedagtes en bespiegelings, Jrg 13/3, bl 3-19.

Die Afrikaner

1971

15 Januarie $\quad$ : Die taak van die kerk in die jare sewentig.

22 Januarie $\quad$ : Kerkleiers en moord op staatshoofde.

29 Januarie : Die WRK en die terroriste.

5 Februarie : Wat sit agter die beroering onder die Anglikane?

12 Febbruarie : Die nuwe teologie en die dilemma van die kerk.

19 Februarie : Ekumeniese bewegings wil die mag aan die nie-blankes cordra.

26 Februarie : Waarom lui alarmklokke nie oor Sabbatsontheiliging nie?

5 Maart : Die kerk sal van hierdie sake kennis moet neem.

12 Maart : Kommunistiese simbool slaan nou ook in SA uit.

19 Maart : Swart Teologie: Nuwe metode om die swartman magsbewus te maak.

26 Maart : Die University Christian Movement en sy toekomsbeplanning.

2 April : Die Herstigte Nasionale Party is nie 'n kerk nie.

9 April : Vyande van die Afrikaner wil die kerk weer laat skeur.

16 April : Weet ons nog vandag wat die gronde vir apartheid is?

23 April : Uitwissing van ras of kleur ter wille van die evangelie is opperste dwaasheid.

30 April : : Aanval op apartheid is gemik teen die Christelike geloof.

$7 \mathrm{Mei} \quad$ : 'Apartheid een van die skoonste vrugte van die Christelike geloof en die Bybel' ... is dit so?

$14 \mathrm{Mei} \quad$ : Gees van gelykmaking in die wêreld het 'n dodelike siekte geword.

$21 \mathrm{Mei} \quad$ : Wie apartheid verwerp, verwerp sy voorgeslag.

$28 \mathrm{Mei} \quad$ : Anglikaanse kerk het min bygedra tot bevordering van die Bybelse teologie. 
4 Junie

11 Junie

18 Junie

25 Junie

2 Julie

9 Julie

16 Julie

23 Julie

30 Julie

6 Augustus

13 Augustus

20 Augustus

27 Augustus

3 September

10 September

17 September

24 September

1 Oktober

8 Oktober

15 Oktober

22 Oktober

29 Oktober

5 November

12 November

19 November

26 November
Die toekoms van die kerk as die kommunisme slaag, 1.

: Die Christelike kerk se toekoms as die kommunisme slaag, 2.

: Parallellisme is niks anders as verkapte integrasie nie.

: Die jare sewentig: 'n Keuse sal gemaak moet word.

: Die All African Churches Conference: Waarvoor dit staan en wat dit doen.

: Die toekoms soos ander dit sien.

: Rassisme: Die nuwe woord van die liberalistiese wêreld en die Wêreldraad van Kerke.

: Hedendaagse modewoorde strydig met geloofsbeginsels.

: Predikante en hulle deelname aan die partypolitiek.

: Enkele gebeurtenisse Christelik beoordeel.

: Basiese waarhede van Afrikanerwees is belangriker as die omstandighede.

: $\quad$ Pro Veritate se Ope Brief eggo linkse denke van Amerika.

: Liberalisme in die kerk en die plig van die kerklike leiding.

: Die kerk in nood: Die Afrikaner moet slapeloos wagstaan.

: Die kerk in nood: Moderne verligtheid en dekadensie.

: Rondom 'n Nasionale Konvensie en die plig van die kerk in SA.

: Integrasie: Sal die kerk in SA vir die blankes 'n antwoord gee?

: Die veranderende tye en die hedendaagse nuwe teologie.

: Jong mense wat die taal van die verlore seun praat.

: Is 'n blanke tuisland onchristelik?

: Een swaeltjie maak nie 'n kerklike somer nie.

: Naakte beelde in Pretoria?

: Johannes Calvyn - ons trots en ons voorreg.

: Vernuwing - deur die Marxisme of deur God?

: Kerke al meer verbind aan oorlog en rewolusie.

: Kerk en vrede: Nuwe denke moet Marxisme bevoordeel. 
3 Desember

10 Desember

17 Desember
: Kerk en vrede: Kyk goed na sommige kerkmanne.

: Die kerk kan ook fouteer.

: Ons tyd, die toekoms en ewige dinge.

1972

14 Januarie

21 Januarie

28 Januarie

4 Februarie

11 Februarie

18 Februarie

25 Februarie

3 Maart

10 Maart

17 Maart

24 Maart

31 Maart

4 April

14 April

21 April

28 April

$5 \mathrm{Mei}$

$12 \mathrm{Mei}$

$19 \mathrm{Mei}$

$26 \mathrm{Mei}$

2 Junie

9 Junie

16 Junie

23 Junie

30 Junie

7 Julie

14 Julie
: Die kerk: Bo-nasionaal of internasionaal?

: Handhawing van die kerk se eiesoortigheid.

: Rondom die ekumeniese beweging.

: Die Afrikaanse kerke ' $n$ invalspoort.

: Swakheid verhoog die gevaar.

: Kerklike integrasie, 1.

: Kerklike integrasie, 2.

: Kerklike integrasie, 3.

: Kerklike integrasie, 4.

: Kerklike integrasie, 5.

: Enkele opmerkings oor die Anglikane.

: Konfrontasie tussen kerk en staat.

: Afrika-teologie - Is dit die antwoord?

: Die gejuig oor die Afrikaner as 'n 'bastervolk'.

: Die onderdrukte Christendom.

: Rondom die begrip vryheid en die kerk.

: Christelik-nasionaal - dan moet ons ons skaam.

: Is dit die prys werd?

: Die WRK en die terroriste.

: Gebrekkige kennis.

: Selfbehoud en die Christelike geloof.

: Pornografie en sy invloed op 'n volk.

: Geloof en liefde.

: Studente-onlus en die Anglikaanse kerk.

: Geloofskrisis in Nederland.

Kerk en kultuur: 'n Paar vrae.

: Devaluasie op kerklike gebied. 
21 Julie

28 Julie

4 Augustus

11 Augustus

18 Augustus

1 September

8 September

15 September

22 September

29 September

6 Oktober

13 Oktober

20 Oktober

27 Oktober

3 November

10 November

17 November

24 November

8 Desember

12 Desember

1973

19 Januarie

26 Januarie

2 Februarie

9 Februarie

16 Februarie

23 Februarie

2 Maart

9 Maart
: Die WRK en Afrika.

: Die magte van links.

: Die Black Peoples' Convention.

: Waardes wat nie meer genoem mag word nie.

: Maatstawwe waarmee gemeet word.

: Wat gebeur nou hier?

: Iets oor die geskiedenis.

: Tyd vir besinning.

: Propaganda vir dialoog.

: Geloofsbelydenis van 'n nasionalis.

: Verandering en vernuwing.

: Nogmaals oor verandering.

: Verandering: Weer 'n keer.

: Die aanval op ons gees.

: Enkele opmerkings oor 'klein apartheid'.

: Diskriminasie: 'n Euwel en 'n vloekwoord.

: Oor die sogenaamde kerkmoles.

: Die gees van Cottesloe.

: Kerklike integrasie.

: Geloftedag.

: Die Afrikaanse kerke in 1973, 1.

: Die Afrikaanse kerke in 1973, 2.

: Die Afrikaanse kerke in 1973, 3.

: Die Afrikaanse kerke in 1973, 4.

: Sydney en Cottesloe.

: GES en gemengde huwelike.

: Die GES en die mens geskape na die beeld van God.

: Die GES en naasteliefde. 
23 Maart

30 Maart

6 April

13 April

27 April

$4 \mathrm{Mei}$

$11 \mathrm{Mei}$

$18 \mathrm{Mei}$

$26 \mathrm{Mei}$

1 Junie

8 Junie

15 Junie

22 Junie

29 Junie

6 Julie

13 Julie

20 Julie

27 Julie

3 Augustus

10 Augustus

17 Augustus

24 Augustus

31 Augustus

7 September

14 September

21 September

28 September

5 Oktober

12 Oktober
Die GES en die eenheid van die kerk.

: Die GES en gesamentlike eredienste.

: Die GES en rassisme.

: Die GES-besluite en die Afrikaner.

: Die kerk en die politiek.

: Loongapings en hoër lone.

: Die kanselboodskap van die Nederduitsch Hervormde Kerk.

: Kerk en pers.

: Oor ons vaderland.

: Onrus oor kerkintegrasie.

: Die neiging na links.

: Gedagtes oor integrasie.

: Oor die begrip verandering, 1.

: Oor die begrip verandering, 2.

: $\quad$ Oor die begrip verandering, 3.

: Saam aanbid en dialoog.

: Gemengde eredienste.

: Teologiese vriende.

: Verligtheid.

: 'n Halwe evangelie.

: Amerikaanse invloede.

: Terrorisme.

: Die Afrikaner en sy kerk, 1.

: $\quad$ Die Afrikaner en sy kerk, 2.

: Die Afrikaner en sy kerk, 3.

: $\quad$ Die Afrikaner en sy kerk, 4.

: Die Afrikaner en sy kerk, 5.

: Die Afrikaner en sy kerk, 6.

: Staan op die ou weë. 
19 Oktober : Uit die kerknotules.

26 Oktober : Die Hervorming.

2 November : Liberalisme en die Bybel.

9 November : Amerikaanse styl.

23 November : Beweging na links.

30 November : : Sagte Afrikaners.

7 Desember : Skuld van die boodskapper.

14 Desember : : 'n Besondere dag.

1974

19 Julie : : Dialoog.

1975

10 Januarie : Predikant en politiek.

17 Januarie : Witman en swartman.

24 Januarie : Verantwoordelikheid.

31 Januarie : Grense.

14 Februarie : Verwarring.

21 Februarie : 'n Wonderwerk.

8 Maart : Stryd en geloof.

14 Maart : Volharding.

21 Maart : Selfbehoud.

28 Mart : : Stryd van die kerk.

4 April : Kerk en wêreld.

18 April : Kerk en Rhodesië.

$2 \mathrm{Mei} \quad$ : Rooi opmars.

$9 \mathrm{Mei} \quad$ : Bont dienste.

$16 \mathrm{Mei}$ : Die vergaderings. 
13 Junie

20 Junie

27 Junie

11 Julie

18 Julie

25 Julie

1 Augustus

8 Augustus

15 Augustus

26 September

31 Oktober

7 November

14 November

21 November

28 November

5 Desember

4 Julie

Geen datum

12 Desember
: Die Christelike Instituut.

: Watter God?

: Die kerk in Afrika.

: Kerk en kommunisme.

: Die kerk en geweld.

: Die Christelike Instituut se verweer, 1.

: Die Christelike Instituut se verweer, 2.

: Jesus 'n sosialis?

: Jesus 'n sosialis?

: Golgota-détente.

: Johannes Calvyn, 1.

: Johannes Calvyn, 2.

: Johannes Calvyn, 3.

: Johannes Calvyn, 4.

: Johannes Calvyn, 5.

: Johannes Calvyn, 6.

: Die Christelike Instituut en sy rol in Suid-Afrika.

: Die NGK, die NHK en integrasie.

: Afrikaanse kerke en die politiek.

1976

Vanaf 1976 het Pont nie meer onder sy eie naam geskryf nie, maar onder die skuilnaam Teoloog. Dit hang saam met die besluit van die Algemene Kerkvergadering 1976 wat ' $n$ ingrypende besluit geneem het oor dienaars van die Woord se deelname aan die partypolitiek. Om nie aanstoot te gee nie en terselfdertyd tog nie sy hulp aan Die Afrikaner te onttrek nie, het hy onder 'n skuilnaam begin skryf. Van sy hand het die volgende in dié tyd verskyn:

16 Januarie : Die jaar 1976.

23 Januarie : Interessante klanke. 
6 Februarie : Kerk en oorlog.

13 Februarie : Verbreekte bande.

20 Februarie : Kerk en Marxisme.

5 Maart

: Ons omstandighede.

19 Maart

: Rhodesië.

26 Maart

: Sedelike verval.

2 April

Kuba en die kerk.

9 April

Die WRK is eerlik.

16 April

Rondom Daniël.

23 April

: Naasteliefde.

$7 \mathrm{Mei}$

Gebrekkige kennis.

$14 \mathrm{Mei}$

: Kerkintegrasie.

$28 \mathrm{Mei}$

: Rooies in die kerk.

4 Junie

: Pinkster.

11 Junie

: Kerk en wêreld.

18 Junie

: Grenslyne.

25 Junie

: Kerk en volk.

2 Julie

: Stryd.

9 Julie

Die Afrikaner en sy kerk.

16 Julie Apartheid.

23 Julie

Oor die Christendom.

30 Julie

: Oor die Ontugwet.

\section{Augustus}

: Die Afrikaanse kerke.

13 Augustus

: Die GES-besluite.

20 Augustus

: Bedreigde fronte.

27 Augustus

: Die tye waarin ons lewe.

3 September

: Die linkse teologie.

10 September : Kyk na Kruger.

17 September : 'n Ander geluid.

24 September : Eerbaarheid. 
1 Oktober

8 Oktober

15 Oktober

22 Oktober

29 Oktober

5 November

12 November

19 November

3 Desember

10 Desember

1977

14 Januarie

21 Januarie

4 Februarie

11 Februarie

25 Februarie

4 Maart

11 Maart

18 Maart

25 Maart

1 April

8 April

15 April

22 April

29 April

$6 \mathrm{Mei}$

$13 \mathrm{Mei}$

$20 \mathrm{Mei}$

$27 \mathrm{Mei}$
: Verantwoordelikheid.

: Vertroue.

: Kerkintegrasie.

: Hervorming.

: Bucer se werk.

: Dit is die Wêreldraad van Kerke.

: Kerk en politiek.

: Hier geen dialoog.

: $\quad$ Moed.

: Rondom die Gelofte.

: Integrasie.

: Kerk en veranderings.

: Waarheen lei die kerke?

: Apartheid en die volk.

: Volharding en gebed.

: Die Aanslag.

: Kerklike eenheid.

: Kerk en wêreld.

: Gebed vir die owerheid.

: Kommunistiese bedreiging.

: Weerstand?

: Verhoudings?

: Teoloë en loterye.

: Buitelandse mening.

: Ons taak.

: Beginselvastheid.

: Die lyn van integrasie.

: Republiekdag. 
3 Junie

10 Junie

17 Junie

24 Junie

1 Julie

8 Julie

15 Julie

22 Julie

29 Julie

5 Augustus

12 Augustus

19 Augustus

26 Augustus

2 September

9 September

16 September

30 September

7 Oktober

21 Oktober

28 Oktober

9 Desember

9 Desember

1978

13 Januarie

20 Januarie

1983

23 November

30 November
: Volharding.

: Imperialisme.

: Kerk en kultuur.

: Kerk en integrasie.

: Volksbinding.

: Die Ontugwet.

: Die Bybel en Marxisme.

: Christelike republiek.

: Hedendaagse kerkleiers.

: Linkse bewegings.

: Boodskap vir vandag.

: Krag van die kerk.

: Hedendaagse modewoorde.

: Afrikanerskap, 1.

: Afrikanerskap, 2.

: Afrikanerskap, 3.

: Twee strome.

: Kerk en gelowe.

: Geloof en ongeloof.

: Kerk en regering.

: Politieke stryd.

: Nasionale bewussyn in gevaar gestel.

: Die nuwe jaar.

: Volk van God.

: Die Christen en die politiek, 1.

: Die Christen en die politiek, 2. 
1984

11 April

18 April

9 Mei

6 Junie

Augustus

10 Oktober

28 November

19 Desember

1985

6 Februarie

13 Maart

31 Julie

14 Augustus

18 September

9 Oktober

11 Desember

1986

29 Januarie

4 Junie

11 Junie

18 Junie

27 Augustus

24 September

17 Desember

1987

8 Julie

28 Oktober

17 Desember

1988

10 Februarie

$18 \mathrm{Mei}$
: Afrikaners opgeroep tot nuwe kulturele volksfront.

: Integrasie in die kerk wil die Afrikaner vernietig.

: Kultuurbewegings in hede en verlede.

: Linkses vyandig teen ons Europese tradisie.

: Afrikanervolkswag moet grense trek.

: Paul Kruger - simbool van Afrikanervryheid.

: Blanke Anglikane in krisis oor Tutu.

: Geloftedag in die nuwe bedeling.

: Geestelike toerusting in die stryd om selfbehoud.

: Afrikaner gewikkel in oorlog van idees.

: Ou veldtog teen die Afrikaner voortgesit in RGN-verslag.

: Die jaarvergadering van die SACC.

: Afrikaanse predikante moet die stem verhef teen die linkse aanslag.

: NIV bedryf teologie van haat teen die Afrikaner.

: Kerklike organisasies met politieke doelwitte.

: Hewige aanslag op kerke.

: Wolwe in skaapsklere.

: Afrikaanse kerke deur ver-linkses geïnfiltreer.

: Deurmekaar of langsmekaar.

: Falanks van ondermyning.

: Die kerk in die wêreld.

: Liberalisme: Die ideologie van selfmoord.

: Die NGK Sinode in stryd met die Afrikanervolk - 8 Julie 1987.

: Kerk en Samelewing bind die NG Kerk aan NP-beleid.

: Geloftedag.

: Die WRK en die soeke na 'geregtigheid en vrede' in SA.

: Die Hugenote na Suid-Afrika. 
10 Augustus

9 November

: Die nuwe teologie en die stryd van die Afrikaner vandag.

: Die Groot Trek le die grondslae van Afrikaner-nasionalisme.

1989

1 November $\quad: \quad$ Kerk en rewolusie.

1990

$30 \mathrm{Mei}$ : Die twee gesigte van die kommunisme.

13 Desember : Van Cottesloe na Rustenburg.

The South African Observer

1985

Augustus : South African Council of Churches - a review.

Oktober : The so-called black anger and unrest in perspective.

Desember : Sasolburg - and after.

1986

Februarie : The wreckers and the builders.

Mei : The three power blocks in the struggle for South Africa.

Julie : There's no alternative to apartheid.

September : The churches and communism.

Oktober : Shambles of black education.

November : Future of the Afrikaner in jeopardy.

Desember : The embattled Afrikaner and the NG Church.

1987

April : Power sharing a fallacy.

Junie : Growing unrest in the church.

Oktober : The NG Church's 'Kerk en Samelewing' a political document.

Desember : Commemorating the Great Trek 1838-1988.

1988

Februarie : Is apartheid really a sin?

Oktober : SWA and the war in Angola.

Desember : Day of the Vow commemoration. 
1989

April : The transition of SWA to Namibia.

Desember : De Klerk's 'New South Africa'.

1990

Februarie : 1990 - A fateful year.

April : Across the Rubicon.

Junie : High cost of NP government.

Augustus : The Church gone astray.

14.10 Memoranda en rapporte aan die Kommissie van die Algemene Kerkvergadering

1959 Enkele aantekeninge in verband met die eenheid van die kerk, afskeiding van die kerk, die kerkregtelike implikasies indien die Nederduitsch Hervormde Kerk van Afrika sou besluit om oor te gaan tot vereniging met ander kerke.

'n Ongevraagde rapport insake die beroep van ds $\mathrm{P}$ M Smith na 'n sinodale pos.

1960 Insake Artikel III en die bepalings wat daaruit voortvloei (Hoofstuk IV, arts $6,7,8)$ : Is dit in stryd met die Skrif en is dit nodig om hierdie artikels anders te formuleer?

Beskrywingspunt vir die Algemene Kerkvergadering in verband met die Proponentseksamen.

1962 Oor die gewoonte of usansie in die kerk.

1963 Rapport oor die handoplegging.

Rapport insake leervryheid.

1964 Die gebruik van die benaming afgevaardigde na kerklike vergaderings.

Die kerklike tug oor nie-belydende lidmate van die kerk.

Memorandum oor die vraag: Kan diensdoende teologiese professore van die kerk of predikante wat met behoud van status uit die amp getree het, as ouderlinge in gemeentes van die kerk dien en as ouderlinge op die 
meerdere vergaderings van die kerk sitting neem? Kan bogenoemde ampsdraers as ouderlinge in die amp bevestig word met gebruikmaking van die formulier vir die bevestiging van ouderlinge?

1966 Rapport insake 'n ontmoeting met pastor Martin Niemöller.

Rapport oor die vraag hoe iemand wat uitgetree het uit die dienswerk van dienaar van die Woord weer tot die dienswerk toegelaat moet word.

1969 Aantekeninge oor die toelating tot die amp van dienaar van die Woord van proponente en teologiese studente wat aan die Universiteit van Pretoria voltyds besig is met die dosering van vakke wat as voorbereiding vir die teologiese studie beskou kan word.

1971 Tydelik-deeltydse predikante.

Opmerkings oor die agtergrond, opkoms en propagering van 'n 'swart teologie'.

1972 Voorlopige aantekeninge oor die verkleining van die Algemene Kerkvergadering.

1973 Die dienstyd van ouderlinge en diakens.

1974 Rapport insake die Wysigingswetsontwerp op Verdediging.

1975 Aantekeninge in verband met die naam van die kerk.

Rapport insake die probleme van die Deutsche Evangelisch-Lutherische Kirche in Suidwes-Afrika.

Aantekeninge in verband met die frekwensie van die prediking.

$1978 \quad$ Uitleg van Bepaling 120.

1980 Wat hoort tuis in 'n kerkorde in die lig van Skrif en Belydenis?

1981 Die betekenis van die meerdere vergaderings ten opsigte van hulle gesag, funksie en handeling in die kerk.

1983 Die Nederduitsch Hervormde Kerk van Afrika en die ander kerke in die Republiek van Suid-Afrika. 
Wie kan 'n dopeling ten doop hou?

Die attestaat en bewys van lidmaatskap.

1986 Die verkleining van die Algemene Kerkvergadering.

Die gemeentevergadering.

1987 Enkele opmerkings oor die geskiktheid van diegene wat toegelaat wil word tot die deeltydse bediening van die Woord.

Deeltydse predikante.

Memorandum in verband met die 'status' van 'n bedienaar van die Woord.

1988 Studiestuk oor Bepaling 26.3 van die Kerkwet.

1989 Die manier waarop Nagmaal gevier word.

Oor die Afrikaanse Protestantse Kerk.

Aantekening: Daar is ' $n$ drietal rapporte aan die Kommissie van die Algemene Kerkvergadering waarvan prof Pont nie meer afskrifte besit nie, naamlik:

1961 : Rapport oor Artikel III.

'n Deel van die rapport is deur prof Pont geskrywe en hy was ook verantwoordelik vir die redaksionele versorging van die rapport.

1964 : Gelyke Feleenthede. Prof Pont het hierdie rapport geskrywe en dit is daarna nagelees deur proff R D Coertze en B J Engelbrecht wat, as hy hom reg herinner, 'n paar kleiner wysigings voorgestel het. Daarna is die memo gepubliseer deur die Kommissie van die Algemene Kerkvergadering.

1967 : Rapport oor die Christelike Instituut geskryf saam met C J Mans. Die rapport is deur die Kommissie van die Algemene Kerkvergadering voorgelê aan die Schlebusch-kommissie van ondersoek na CISA. 


\section{Literatuurverwysings}

Pont, A D 1986. Verbond en volkskerk. HTS 42, 28-76.

--- 1990. Ongepubliseerde herinneringe. Pretoria: KITAL. 